\title{
The Knowledge Building International Project as an Innovative Learning Environment
}

\section{Le projet international de construction des connaissances en tant qu'environnement d'apprentissage innnovateur}

Josep Gallifa, FPCEE Blanquerna, Ramon Llull University, Barcelona

Mireia Montané, Col.legi de Doctors i Llicenciats en Filosofia i Lletres i en Ciències de Catalunya, Barcelona

Sandra Lund, Global Skills Network S.L., Barcelona

Carme Amorós, Societat Catalana de Pedagogia, Institut d'Estudis Catalans

Mercè Bernaus, Universitat Autònoma de Barcelona, Facultat de Ciències de l'Educació

Mercè Gisbert, Universitat Rovira i Virgili, Facultat d'Educació i Psicologia

Francesc Martínez-Olmo, Facultat d'Educació, Universitat de Barcelona

\begin{abstract}
The Knowledge Building International Project (KBIP), implemented in a network of eight schools in Catalonia, demonstrates the value of an Innovative Learning Environment (ILE) towards supporting dialogical, technological, and systemic dimensions in teaching and learning. Using a design-based research (DBR) approach, a survey queried teachers, students, and external stakeholders regarding their perceptions about educational innovation. The results provide both the profile and the innovative nature of the whole KBIP experience at each participating school. The main results help illustrate the potential of KBIP methodologies. The findings exemplify the value of this particular DBR method for evaluating educational innovations.

Keywords: Knowledge Building; Knowledge Forum; design-based research; Innovative Learning Environments; evaluation; innovation in education

\section{Résumé}

Le Projet International de Construction des Connaissances (PICC) (ou Knowledge Building International Project, KBIP, en anglais) mis en œuvre dans un réseau de huit écoles en Catalogne, démontre la valeur d'un environnement d'apprentissage innovateur (EAI) pour soutenir les dimensions dialogique, technologique et systémique dans l'enseignement et l'apprentissage. En utilisant une approche de recherche orientée par la conception (ROC), une enquête a interrogé des enseignants, des étudiants et des intervenants externes sur leurs perceptions de l'innovation
\end{abstract}


pédagogique. Les résultats fournissent à la fois le profil et la nature novatrice de l'ensemble de l'expérience PICC dans chaque école participante. Les principaux résultats permettent d'illustrer le potentiel des méthodologies PICC. Les résultats illustrent la valeur de cette méthode ROC particulière pour évaluer les innovations éducatives.

Mots-clés : Construction des connaissances ; Forum de connaissances ; recherche orientée par la conception ; environnements d'apprentissage innovateurs ; évaluation ; innovation dans l'éducation

\section{Introduction}

\section{Knowledge Building}

Knowledge creation and use is a critical issue for socioeconomic development in the information societies in which we live. For many years, distributed expertise and networked activities have characterized the emerging work in the knowledge age (Järvelä et al., 2001). This trend has affected the development of alternative innovative educational methods. In this development, computers play an important role for restructuring teaching-learning processes to better prepare learners for future challenges (Järvelä et al., 2001). Computer-supported collaborative learning (CSCL) was considered one of the most promising innovations to improve teaching and learning using modern information and communication technology (Järvelä et al., 2001). CSCL brought together pedagogy, technology, and content as dimensions that must be combined in an integrated approach for teaching with technologies because they are interdependent (Harris et al., 2009).

The Knowledge Building International Project (KBIP) was initiated by Canadian cognitive psychologists Marlene Scardamalia and Carl Bereiter (Scardamalia \& Bereiter, 2006, 2014). Their approach combines the psychological constructivist principles of Knowledge Building (KB) with the use of technology in a digital platform, the Knowledge Forum ${ }^{\mathrm{TM}}(\mathrm{KF})$, to support collaborative learning for knowledge creation. The KF facilitates a higher level representation or organization of ideas (Scardamalia \& Bereiter, 2010, p. 9). Together, KB and KF constitute the main elements of the KBIP, which was brought to Catalonia initially for the 2004-2005 academic year. Eight schools cooperated in KBIP, renamed COMconèixer, which means how to build knowledge together in Catalan. Preliminary evaluations of that experience were carried out for an ongoing process of continuous improvement (Consell Superior d'Avaluació del Sistema Educatiu de Catalunya, 2006, 2015; Mateo et al., 2016).

\section{Evaluation of Educational Innovations}

Evaluation is a key issue in educational innovations. As a single evaluation cannot fully capture student learning, one effective strategy might be to multiply the number of measurements, thereby providing the necessary input for systems based on accountability, diagnosis, and assessment of the effectiveness of innovative practice (Looney, 2009). Evaluation can address how different learning environment designs contribute to learning, cooperation, motivation, etc. (Collins, 1992).

In higher education there are many studies based on student perceptions (Gallifa, 2009a, 2009b; Gallifa \& Batallé, 2010), but these are less common in primary and secondary education. There are some interesting examples to consider, including the study of school climate and the 
relationship of climate dimensions to the adaptation of students who attend middle-grade level schools (Brand et al., 2003). In another example, involving research on teacher perceptions of innovation adoption, an especially meaningful study for our purpose, a multiple-method approach was used to facilitate an examination of the individual's role in the change process of innovation adoption (Gray, 2001).

A variety of models and methodologies for assessing learning outcomes in CSCL settings have been reported in the literature (Law, 2005). Current practice in human-computer interaction advocates usability evaluation as a critical part of every design process. "The choice of evaluation methodology must arise from and be appropriate for the actual problem or research question under consideration" (Greenberg \& Buxton, 2008, p. 111).

\section{Innovative Learning Environments}

Fullan (2005) pointed to the need to change strategies in educational reforms and argued that reforms should connect better with learning outcomes as criteria for sustainable educational practices. By connecting the results of educational research with the evolution of technologies, Istance and Dumont (2010, p. 334) proposed the convenience of defining learning environments following the $21^{\text {st }}$ century social, educational, and technological changes. Meanwhile, other authors indicated the need to include educational equity (Alegre \& Ferrer, 2010) and focus on the social aspects of learning and communities of practice (Blackmore, 2010).

The need to understand teaching and learning as social practices, alongside the use of learning spaces and technologies, influenced the agenda for research in innovative learning environments (Blackmore et al., 2011). The Organisation for Economic Co-operation and Development (OECD) considered this approach of joining innovation, research, and learning environments (2013). After diverse reports, the same OECD (2017) proposed the traits by which any educational innovation should be considered as an ILE.

The OECD recently refined thes common ILE traits based on the work of different researchers, and also on the observation of relevant educational innovations in various countries (OECD, 2017). That document synthesized several studies and proposed seven principles that all ILEs adhere to (OECD, 2017). Three additional dimensions were cited as being necessary to optimize the conditions that are required to implement the seven principles, hence the " $7+3$ " framework (Table 2).

Knowledge Building has been presented as an approach to fulfill the need to educate for innovation. It fits into the larger picture of education for innovation as seen from points of view of research in the learning sciences and the OECD's studies of innovation in education (Bereiter et al., 2016). The question that always arises is: How can innovative learning environments be evaluated? Many evaluations concerning KBIP have been carried out, but not in the direction of whether projects like KBIP indeed constitute an ILE for participants as defined by the OECD. The purpose of the present research is to determine if KBIP accomplishes the traits of an ILE. Our study sought to contextualize its findings within the larger body of research on ILE and innovation in education, particularly as it pertains to learning and teaching in primary and secondary education.

Generally speaking, research about innovation can be dialogic (Arnseth \& Ludvigsen, 2006), which means how the discourse about innovation is perceived by participants. At a more general 
level, there is a need for multiple methods for evaluating innovations. This study aims to contribute toward filling these gaps.

\section{Background Information}

\section{Principles of Design-Based Research Applied to the Evaluation of Educational Innovations}

Effective leadership for innovations that integrate technologies needs to build "professional capacity including providing teachers with opportunities to learn, creating communities of practice for them, considering their individualized needs, and addressing issues of access and support" (Dexter \& Richardson, 2019, p. 1). For this reason, the methodology of design-based research (DBR) was selected for this study (Akker et al., 2006). DBR in education is grounded on a systematic process of analysis, design, development, and evaluation of an intervention (a training program, a product, or a process) as a solution to a complex educational problem (Plomp \& Nieveen, 2010).

Summarizing the contributions of different authors (Gallifa, 2018a; Reeves et al., 2002), the traits of DBR have been identified as:

- focussing on complex problems in real contexts;

- involving intensive collaboration between researchers and practitioners;

- integrating recognized and hypothetical design principles to provide solutions to the complex problems that have a possible solution;

- supporting the development of rigorous and reflective studies to experience and improve innovative learning environments as well as define new design principles;

- requiring a long-term involvement that allows continuous improvement of protocols and issues; and

- maintaining commitment both to the construction and theoretical extension and to the resolution of problems in the real world.

The DBR approach embeds three principles (Gallifa, 2018b):

- recursive (iterative): iteration is a design and developmental process that allows practitioners and researchers to review and reformulate processes;

- reflective: assumes that most professional practice problems cannot be solved with preconceived solutions alone; and

- participatory: reflects the change of perspective by considering the expert, the researcher, and the designer as part of the same team with attributions at any of the stages of the research process.

DBR is also considered a mixed and dynamic methodology since some decisions are already made while others have to be made during the research process. This justifies that some methodological concretions cannot be defined or explained a priori. DBR is not defined by the methods it uses, but by the objective that it pursues, which is the grounded innovation (Bereiter, 2002).

The research process using DBR is structured in three phases and has a cyclical nature (McKenney, 2001) as summarized below: 
1. preliminary phase: where the research problem and the characteristics of the context are analyzed at the same time so that a consistent conceptual framework is developed, based on a comprehensive review of the literature and on the real needs of the context that must be the object of study;

2. prototype creation phase: where a prototype of the intervention (program or product) is designed, developed, reviewed, and cyclically repeated. This process allows for progressively achieving a more advanced and complex prototype;

3. evaluation phase: where the effectiveness of the intervention is analyzed and the principles of design are documented and elaborated.

Nieveen (1999, p. 128) affirms that to guarantee quality in the application of a DBR methodology, four criteria must be taken into account: relevance (validity of content), consistency (construction validity), feasibility, and efficacy. In order to achieve the four, it will be necessary to define the corresponding mechanisms and verification strategies.

\section{Descriptive Traits of the Educational Innovation KBIP in Catalonia}

KBIP was initiated in Catalonia in 2004-2005, with the participation of 10 schools and 300 students. Two written reports of the experience have been published since then, directed to a local audience (Consell Superior d'Avaluació del Sistema Educatiu de Catalunya, 2006, 2015). By 20182019 , the number of participant schools had decreased to eight while the number of students increased to 837 .

KBIP was a good candidate for DBR. It focused a complex problem because it involved collaborative learning, the use of technology, and the evaluation of an educational innovation. There was also an intensive collaboration between researchers and practitioners on the team that cooperated in the implementation of the KBIP innovation and, at the same time, in the evaluative phase. During the 2018-2019 academic year, the DBR team was formed and was composed of the project leaders, two researchers from two universities, and 13 teachers. This team met once a month. The KF was used for students to work on different topics that included sustainable development, migrations, Gandhi, Gaudí, gender equality, and Al-Andalus and Islam, among others. Teachers, external agents, and others joined the evaluation phase of the project.

\section{Method}

\section{Evaluation Phase}

The participative research team, with representation by teachers and university researchers, decided on the DBR process to evaluate the learning experience focused on educational innovation. An in-depth discussion process prompted the decision to study participants' perceptions about the project's educational innovation to answer the research question of whether KBIP could be considered an ILE.

A survey (Appendix A) was constructed and administered to teachers, students, and external stakeholders involved in the KBIP experience, with triangulation of data anticipated to increase the reliability of the findings. While some items served to evaluate the experience from a pedagogical and technological perspective of the KBIP experience (including some of the 12 principles of KB) 
(Scardamalia, 2002), other items were directed towards evaluating participant satisfaction with the experience (Appendix B). Survey construction included a Likert scale (0-5, no middle point) and items covering the $7+3$ traits of an ILE, and also included age-appropriate language adaptation for student participation. In this process, the contribution of teachers was invaluable, as illustrated:

- teachers/external stakeholders ${ }^{1}$ : I actively encourage well-organized cooperative learning; and

- students/learners: I learn cooperatively in an organized way.

For each survey question, a supplementary item also using a Likert scale, attempted to compare KBIP with other ILEs by asking whether KBIP was more innovative than other educational innovations relative to the item. These were posed to elicit feedback regarding the perception of innovation compared with other classroom activities in schools that had been implementing other innovative programs in addition to KBIP.

\section{Process}

1. Administer the survey (Likert scale) to:

- teachers (KBIP participants);

- students (KBIP participants); and

- external stakeholders: directors/study coordinators/external auditors.

2. Triangulate the results to answer the initial question: Can KBIP be considered an ILE? (OECD Objective 1).

3. Evaluate the KBIP experience from the perspective of the participants and in alignment with the 12 principles of KBIP (OECD Objective 2).

Applied research methodologies followed ethical norms and standards of working with humans and minors as research subjects. Upon concluding deliberations regarding the DBR language adaptation, researchers decided against administering the questionnaires to three participating primary schools (Grades 2-6), as teachers argued that the language was not age-appropriate. Additionally, one secondary school opted out of the survey since KBIP had not been fully implemented to yield relevant findings. Thus, four of the eight participating schools administered the survey, with the majority of their teachers responding. The survey sample was considered sufficiently representative for the research project while supporting the logic of iteration in DBR, as well as providing the justification to start a new phase of the project.

\section{Table 1}

Sample of the Evaluation Phase

\begin{tabular}{lr}
\hline 2018-2019 Study & Number \\
\hline Secondary Education-Middle Schools & 4 \\
Students & 404 \\
Teachers & 11 \\
External Stakeholders & 10 \\
\hline
\end{tabular}

\footnotetext{
${ }^{1}$ OECD language
} 


\section{Findings}

Table 2 shows the survey results in context of the $7+3$ criteria for ILE.

\section{Table 2}

OECD Principles and Survey Results

\begin{tabular}{|c|c|c|c|c|}
\hline Principles and Items & Students & Teachers & External & Mean \\
\hline $\begin{array}{l}\text { 1. The learning environment recognizes the learners as } \\
\text { its core participants }\end{array}$ & 6.48 & 8.18 & 8.44 & \\
\hline encourages their active engagement & 6.46 & 7.80 & 8.22 & \\
\hline $\begin{array}{l}\text { and develops in them an understanding of their own } \\
\text { activity as learners }\end{array}$ & 6.62 & 8.36 & 7.56 & 7.50 \\
\hline $\begin{array}{l}\text { 2. The learning environment is founded on the social } \\
\text { nature of learning }\end{array}$ & 7.08 & 8.36 & 8.00 & \\
\hline $\begin{array}{l}\text { and actively encourages well-organized co-operative } \\
\text { learning }\end{array}$ & 6.80 & 8.54 & 8.00 & 7.79 \\
\hline $\begin{array}{l}\text { 3. The learning professionals within the learning } \\
\text { environment are highly attuned to the learners' } \\
\text { motivations }\end{array}$ & 6.70 & 8.00 & 9.50 & \\
\hline and the key role of emotions in achievement & 6.42 & 7.64 & 8.24 & 7.70 \\
\hline $\begin{array}{l}\text { 4. The learning environment is acutely sensitive to the } \\
\text { individual differences among the learners in it }\end{array}$ & 6.42 & 7.10 & 8.44 & \\
\hline including their prior knowledge & 6.68 & 8.54 & 8.88 & 7.59 \\
\hline $\begin{array}{l}\text { 5. The learning environment devises programs that } \\
\text { demand hard work, and }\end{array}$ & 6.82 & 7.10 & 8.44 & \\
\hline challenge from all & 6.58 & 8.00 & 8.44 & \\
\hline without excessive overload & 8.79 & 9.09 & 10.00 & 8.14 \\
\hline $\begin{array}{l}\text { 6. The learning environment operates with clarity of } \\
\text { expectations, and }\end{array}$ & 6.72 & 7.46 & 7.20 & \\
\hline $\begin{array}{l}\text { deploys assessment strategies consistent with these } \\
\text { expectations }\end{array}$ & 6.94 & 8.00 & 7.80 & \\
\hline $\begin{array}{l}\text { there is strong emphasis on formative feedback to } \\
\text { support learning }\end{array}$ & 6.90 & 8.18 & 7.50 & 7.35 \\
\hline $\begin{array}{l}\text { 7. The learning environment strongly promotes } \\
\text { "horizontal connectedness" across areas of knowledge, } \\
\text { and }\end{array}$ & 6.74 & 8.72 & 9.12 & \\
\hline subjects, as well as & 6.78 & 9.28 & 9.78 & \\
\hline to the community and the wider world & 7.28 & 8.72 & 9.78 & 8.45 \\
\hline
\end{tabular}




\begin{tabular}{|c|c|c|c|c|}
\hline Principles and Items & Students & Teachers & External & Mean \\
\hline $\begin{array}{l}\text { 1. Innovate the pedagogical core of the learning } \\
\text { environment, whether the core elements (learners, } \\
\text { educators, content and learning resources), or }\end{array}$ & 7.24 & 7.80 & 8.44 & \\
\hline $\begin{array}{l}\text { the dynamics which connect them (pedagogy use of } \\
\text { time and the organization of educators or learners) } \\
\text { and }\end{array}$ & & 8.54 & 8.44 & \\
\hline formative evaluation & & 8.18 & 7.76 & 7.98 \\
\hline 2. Become "formative organizations" & 6.68 & 8.18 & 8.22 & \\
\hline with strong learning leadership & 6.36 & 6.54 & 7.50 & \\
\hline constantly informed by evidence about the learning & 6.64 & 7.08 & 8.74 & \\
\hline achieved through different strategies and innovations & & 7.82 & 8.22 & 7.35 \\
\hline $\begin{array}{l}\text { 3. Open up to partnerships by working with families and } \\
\text { communities, higher education, cultural institutions, } \\
\text { media, business and especially other schools, and }\end{array}$ & 7.46 & 8.36 & 9.34 & \\
\hline $\begin{array}{l}\text { learning environments in ways that directly shape the } \\
\text { pedagogical core and the learning leadership }\end{array}$ & & 8.36 & 8.88 & 8.43 \\
\hline Total Means & 6.74 & 7.77 & 8.31 & 7.71 \\
\hline
\end{tabular}

Note. Blanks in some cells, corresponding to student responses, mean that this item was not included in the survey. Results transformed from $0-5$ to a $0-10$ scale.

Results from the three groups studied are between 6.3 and 10 (on a 0-10 scale). Mean scores in each of the $7+3$ items range between 7.35 and 8.45 (on a $0-10$ scale). The total mean average is 7.71. The values representing perception from the participants' perspective can be considered high, thus illustrating how KBIP demonstrates the traits of an ILE.

Any item of the survey can be represented in a single figure. For example, Figure 1 shows a comparison of the three groups' responses.

The pattern of the scores shows student responses one-to-two points below teacher and external stakeholder responses, reflecting a tendency of the adults answering "strongly agree" versus a more moderate response of "agree" or "slightly agree" from students. Moreover, the student sample is much larger than the other two groups combined. The results of student participants as a group demonstrate a different pattern in relation to the uniformity of the other samples. Conversely, there is an approximation of scores amongst the three groups in terms of meeting criteria \#5 and \#6 of the seven ILE traits, as well as \#1 and \#3 of the three additional dimensions $(+3)$. These refer to the kind of work accomplished, the clarity of expectations and feedback, the innovative character of KBIP, and its potential for fomenting relationships, and reflect areas where participants more closely coincided in their answers. 


\section{Figure 1}

Two of the Items Comparing the Three Groups

A

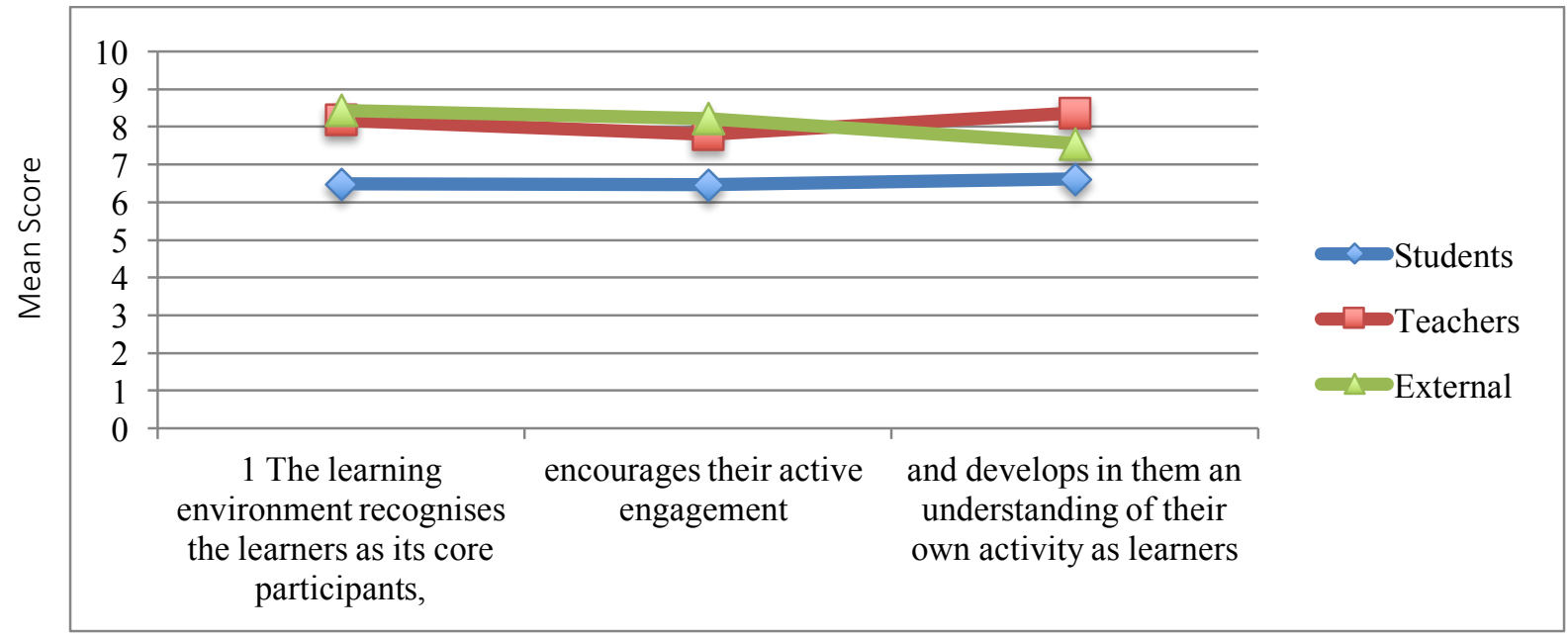

B

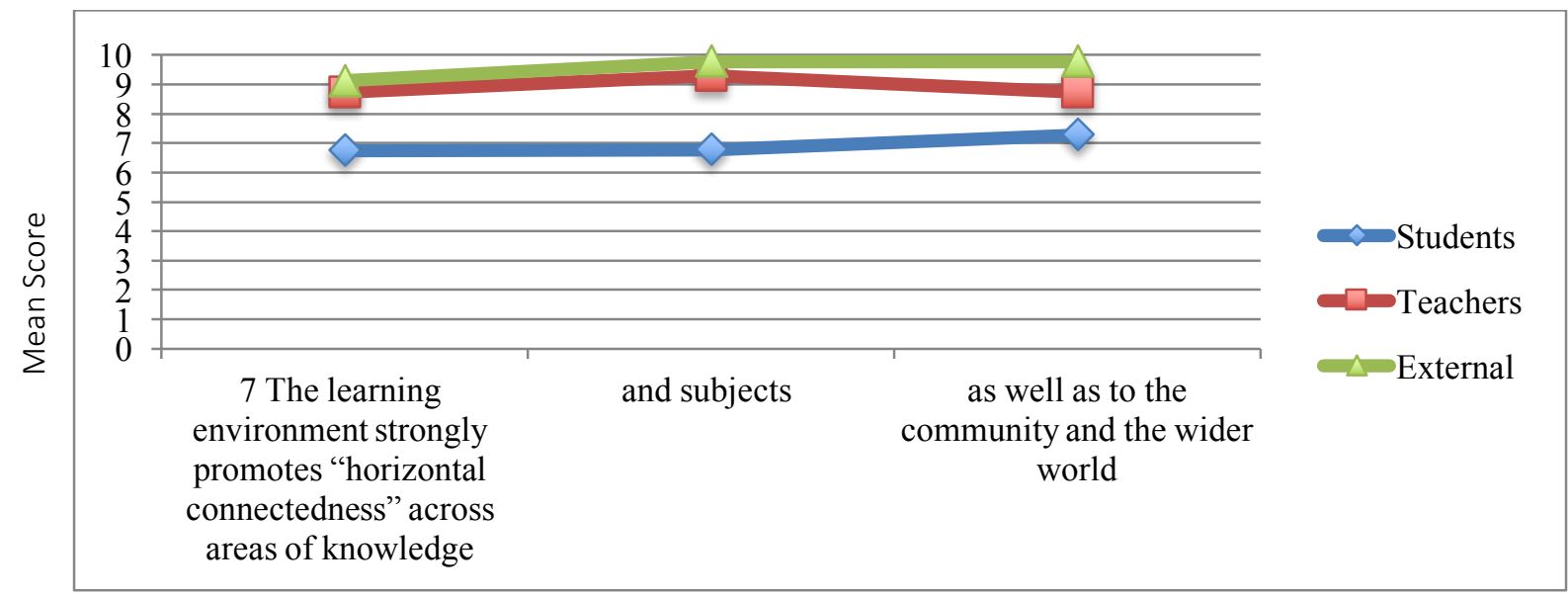

Additionally, there are complementary results concerning the comparison between KBIP and other ILEs. In these items, the percentages are obtained counting the subjects that affirm that KBIP is more innovative than other ILEs. In the case of students, the comparison is with all the other activities of the school (including innovative activities). This opposition made the contrast even stronger. For that reason the percentages in the sample of students are generally lower than those of teachers or external stakeholders. 
Figure 2

Percentages for "KBIP is More Innovative than Other ILE”

A

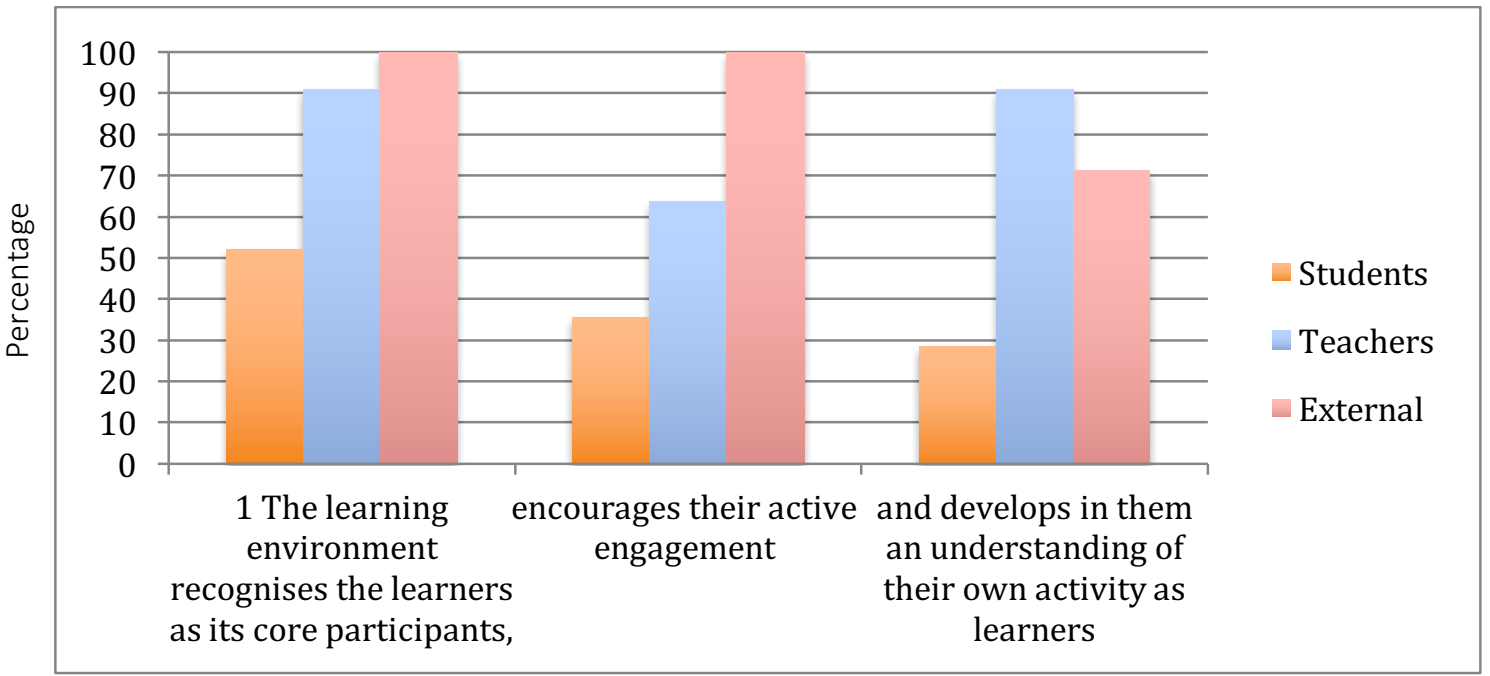

B

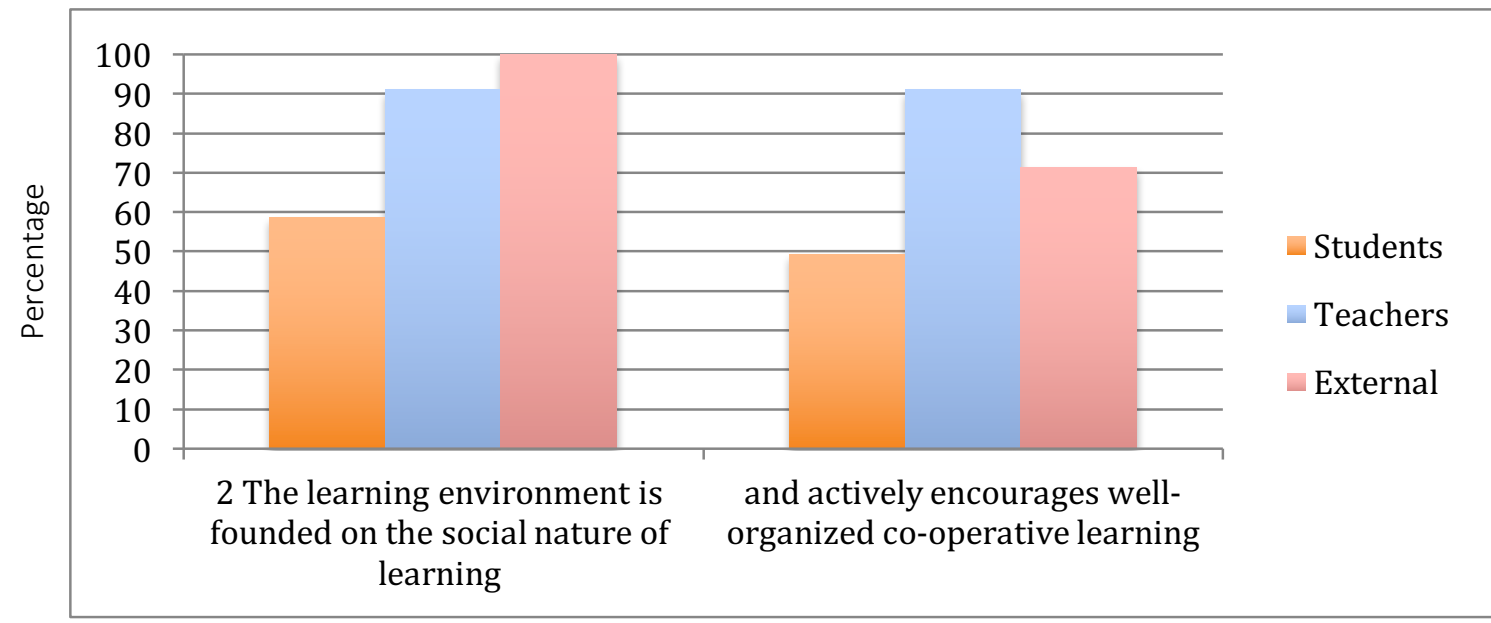

C

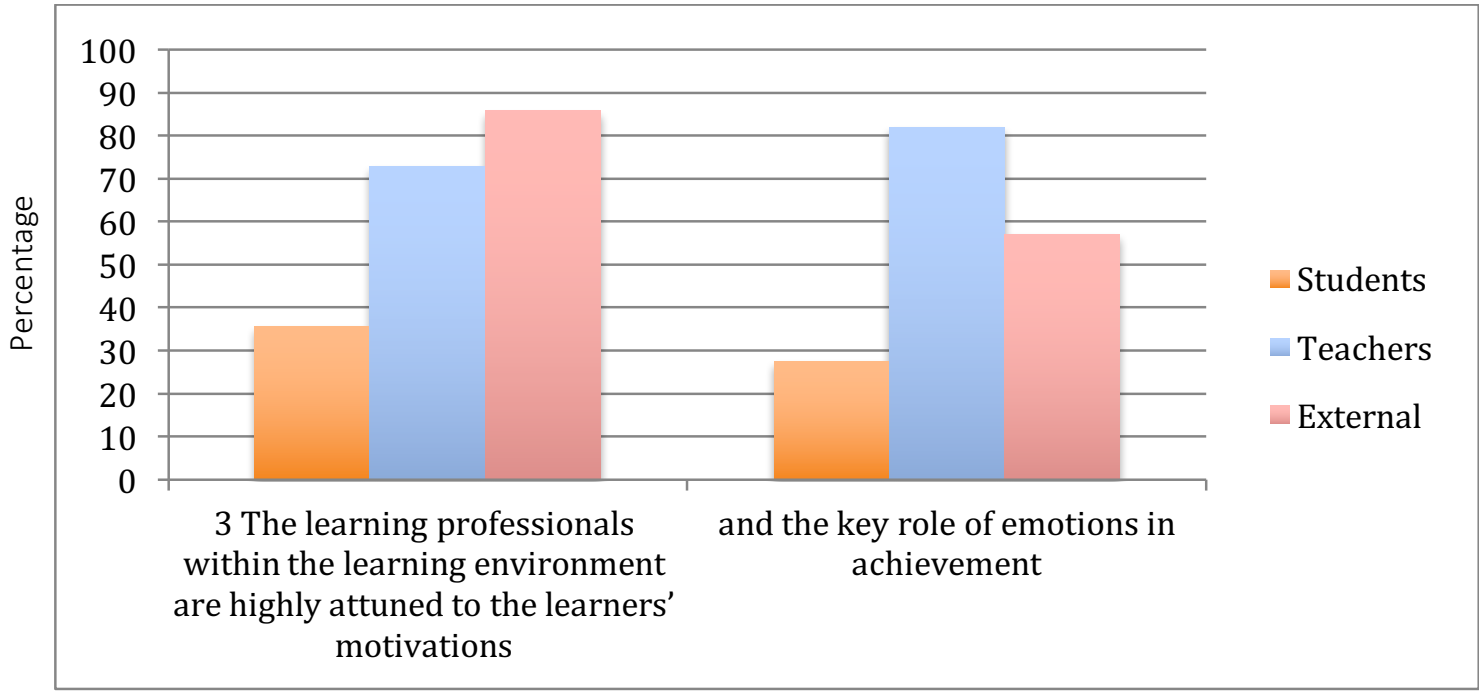


D

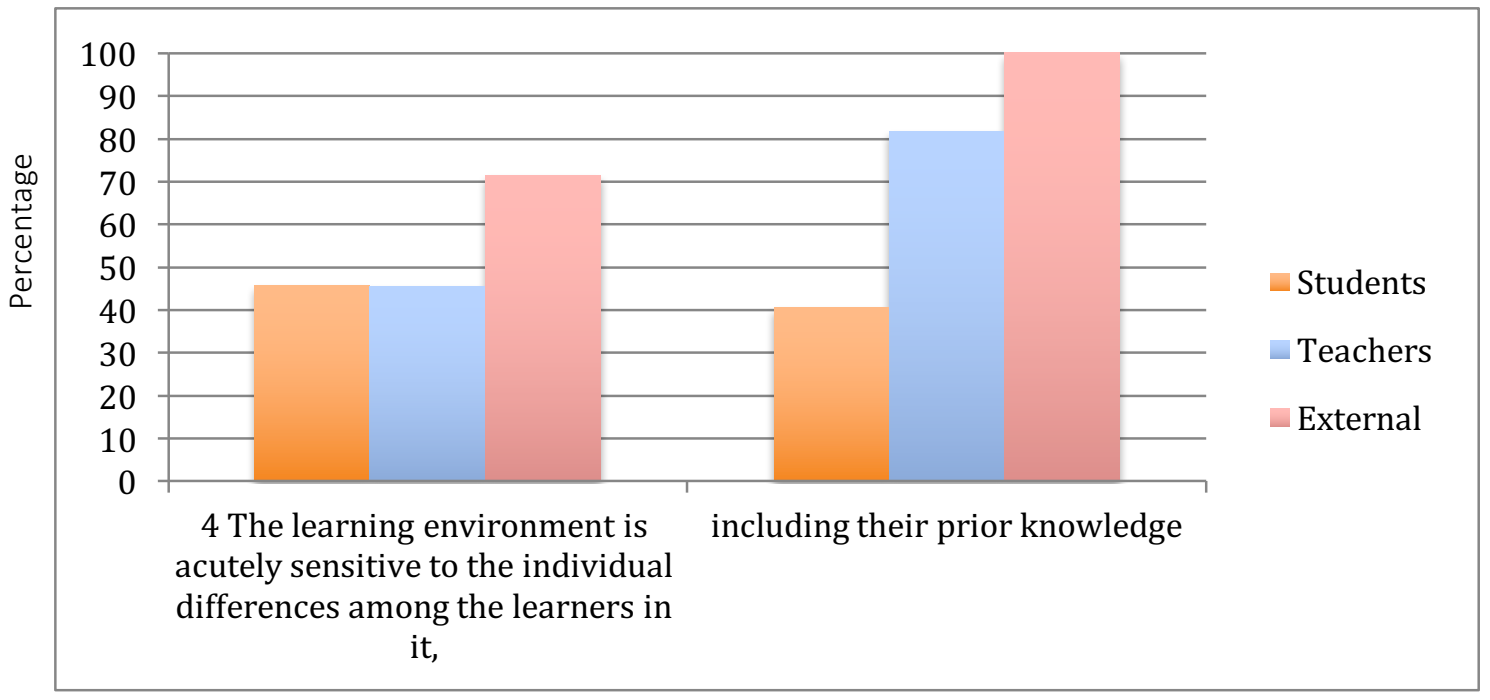

E

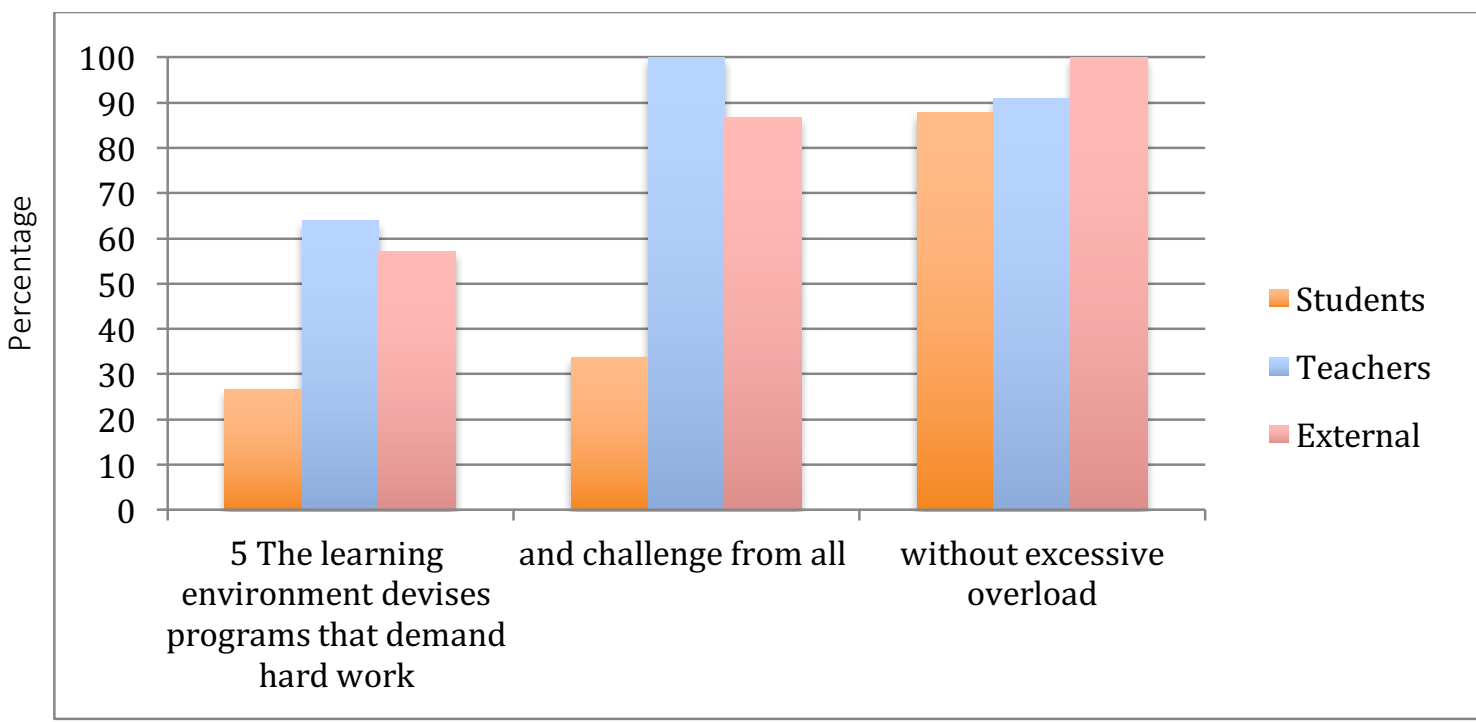

F

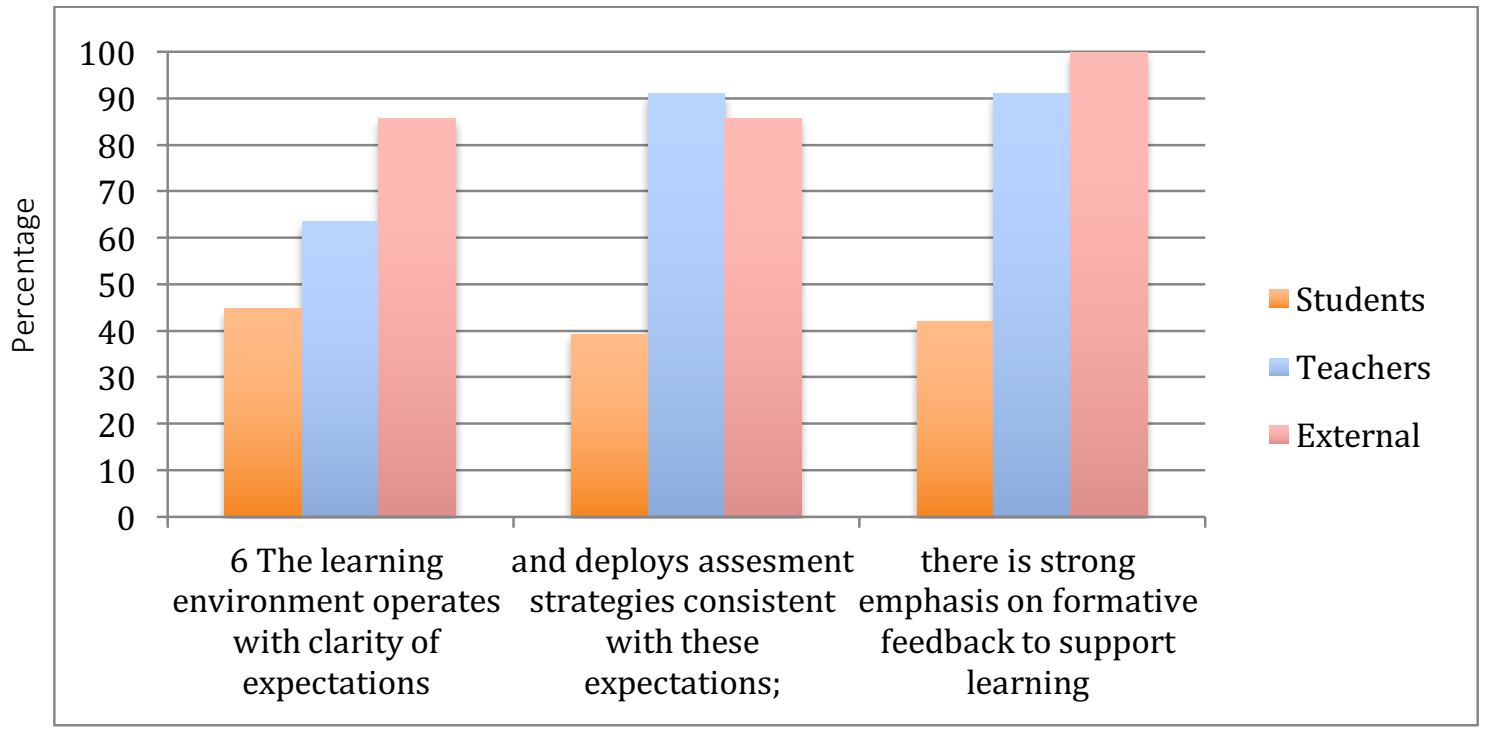


G

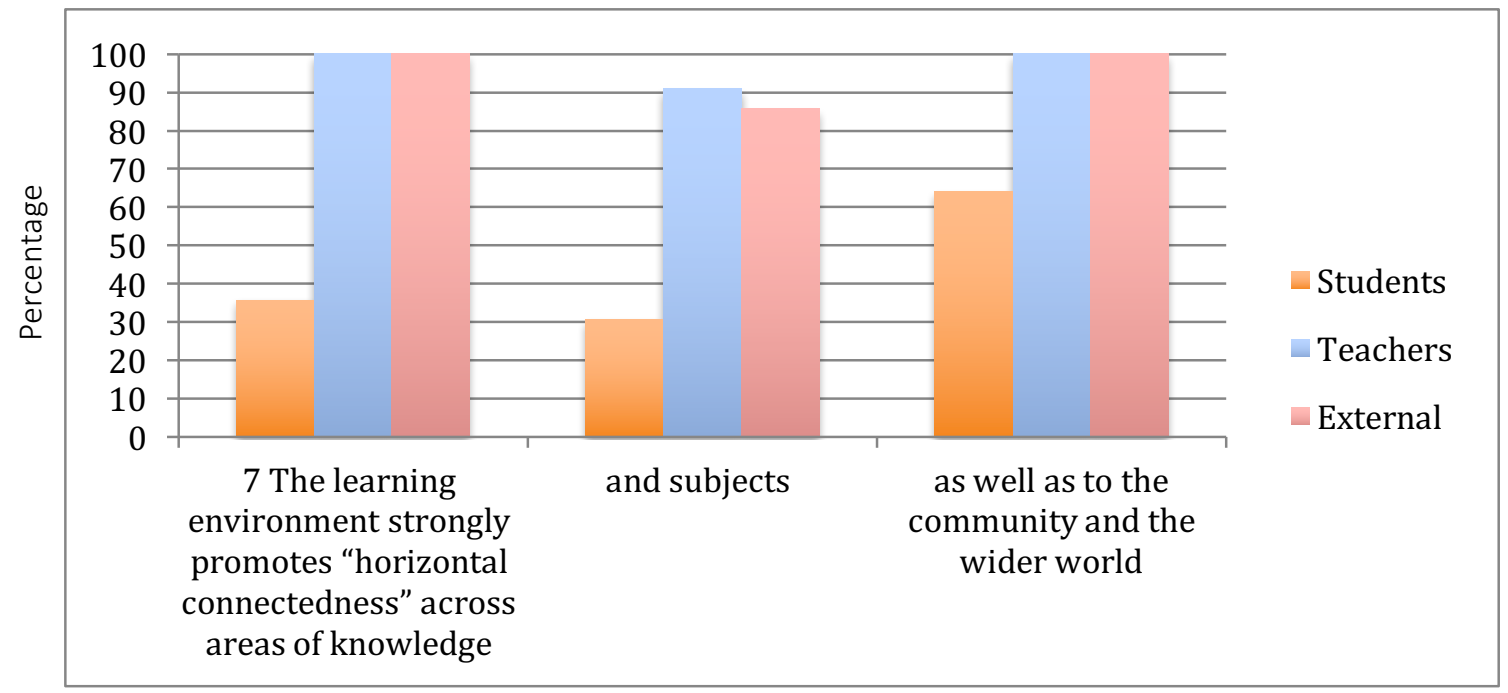

$\mathrm{H}$

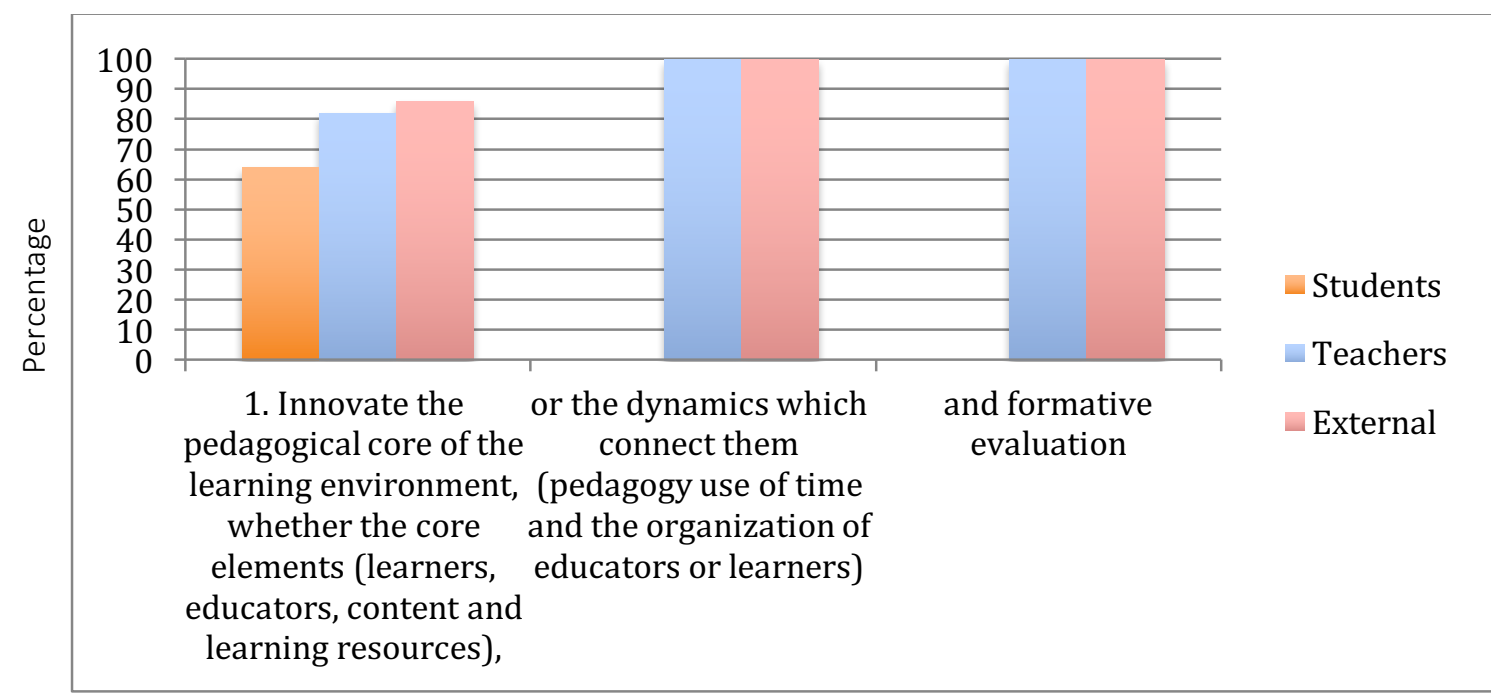

I

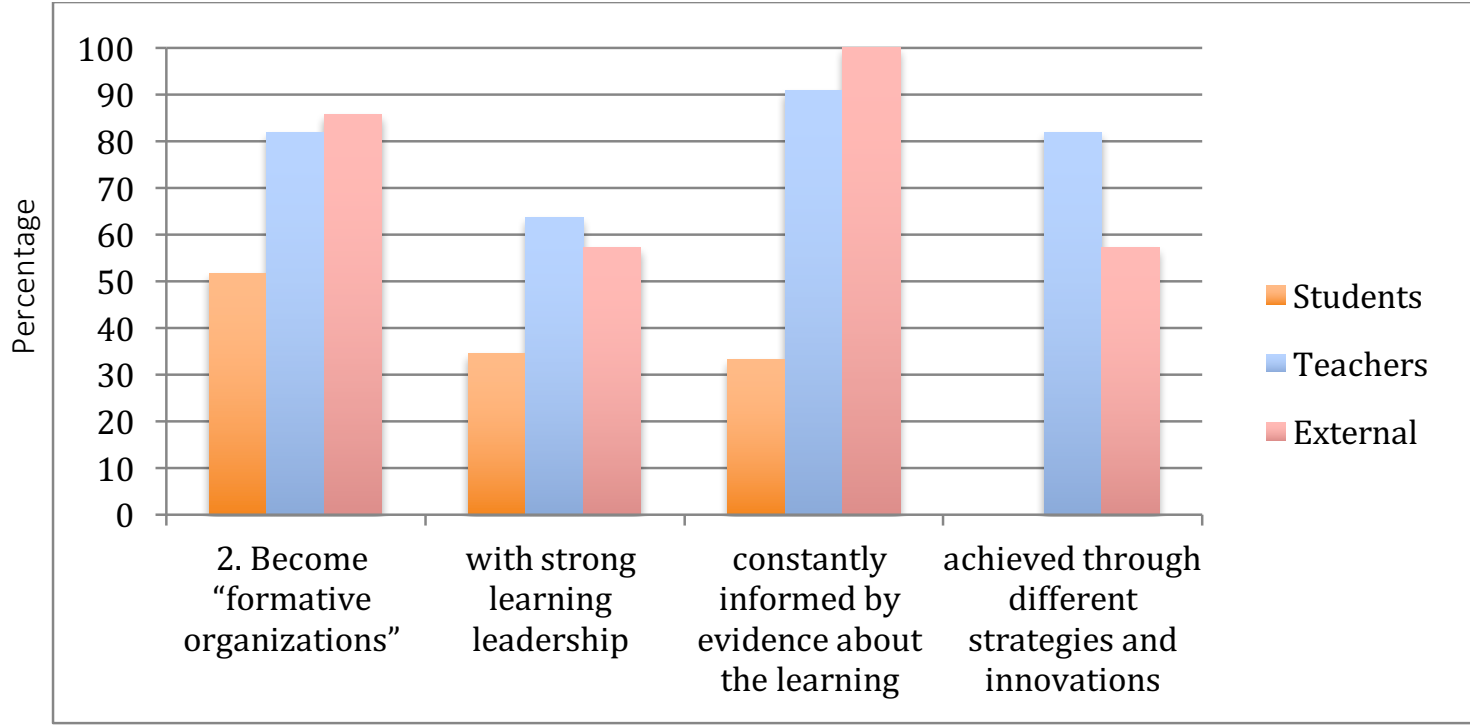




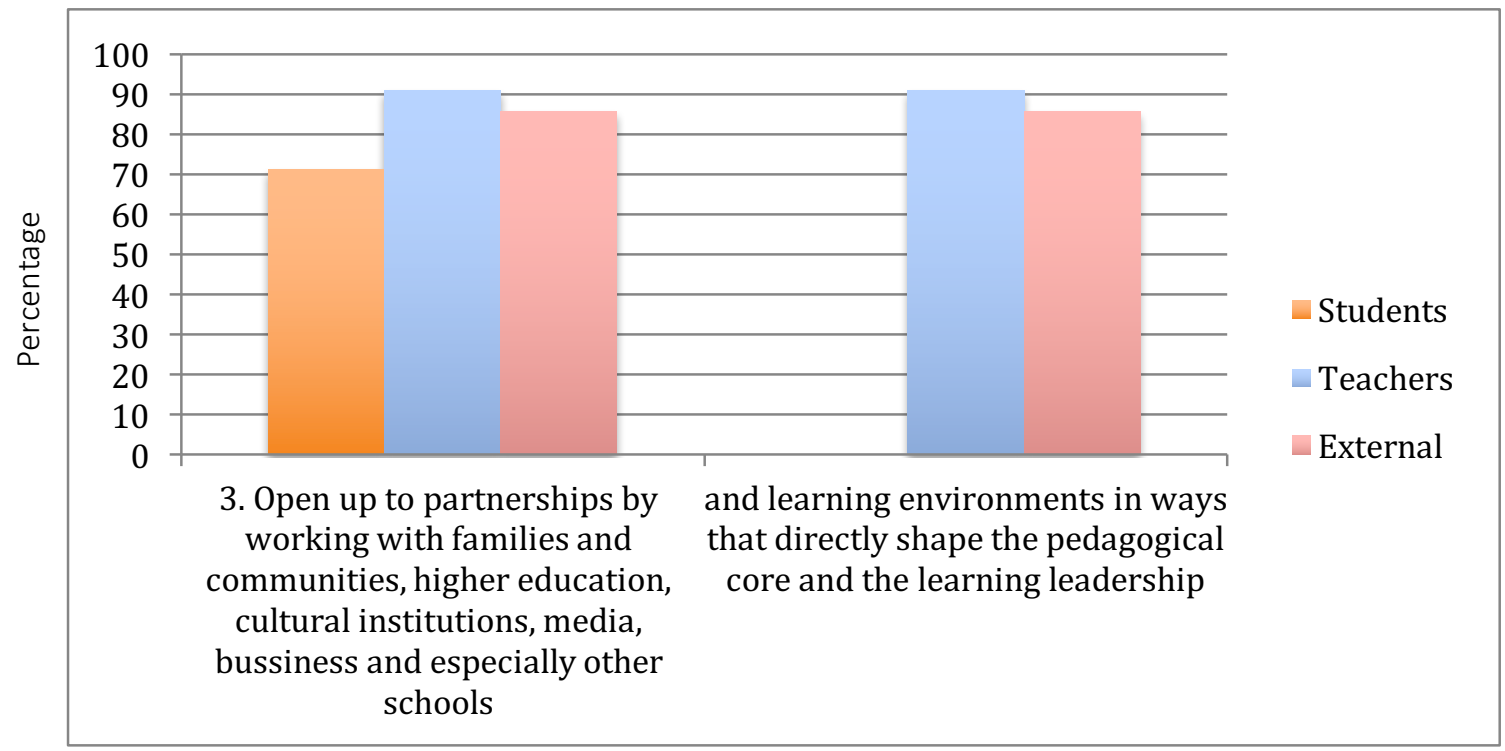

These results allow a more precise analysis of student perception regarding the innovative nature of KBIP. We established $40 \%$ as a turning point, as this represents a high percentage of students affirming that KBIP is a more innovative ILE than all other school activities in innovative schools. Thus, KBIP was perceived as being more innovative by meeting criteria \#2, \#4, and \#6 of the seven OECD ILE traits plus \#1 and \#3 of the +3 additional dimensions. In all other criteria one of the items is over $40 \%$ among student respondents, which means that at least part of the criteria is perceived as more innovative than other school activities. Results clearly indicated that students affirmed several different aspects related directly with the aim of the study, such as the high marks given to the component of perceived innovation (\#1 of the +3$)$, as well as community and working with others (parts of \#7 in the seven OECD ILE traits and \#3 in the +3).

The relative coincidence of scores in the student and external groups in the consideration of the "key role of emotions" in contrast with the more positive perception of teachers (item \#3) is interesting. The coincidence of the three groups in the "no excessive overload in work" (item \#5) is also relavant.

The mean of percentages of Figure 2 was $45 \%$ in students, and $84.5 \%$ and $86 \%$ in teachers and external stakeholders, respectively. In the case of students, the comparison of the KBIP innovation is made with all other school activities, and arguably $45 \%$ can be considered a meaningful rate. Survey results show $100 \%$ of the items for teachers and external stakeholders and $63 \%$ of the items for students were perceived as being more innovative in KBIP than other ILEs. Therefore, it has been demonstrated that, in general, KBIP was perceived as more innovative than other ILEs in the same educational contexts. KBIP aligns with $100 \%$ of the $7+3$ OECD framework for ILEs, demonstrating without a doubt that KBIP should be considered an ILE.

\section{Discussion}

The results can be represented item-by-item for each participating school. Figure 3 provides one example. 


\section{Figure 3}

Differences in Scores Between Teachers-Students Among Schools

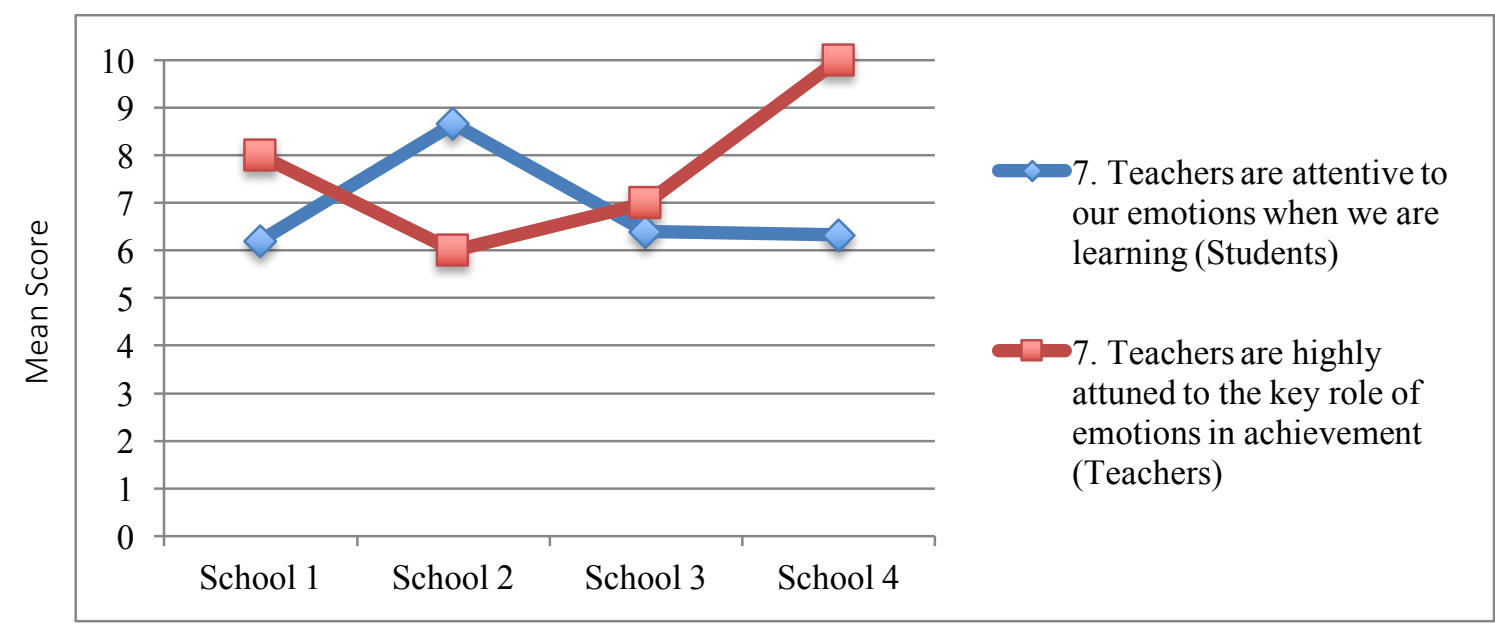

In this example, the differences between schools in perceptions about the role of emotions can be easily observed. The student population of School 2 was unique because their special needs were prompted by the recent immigration of many students and their families to Catalonia.

The results can also be represented item-by-item differentially per grade (Grades 1-4). Figure 4 provides an example.

\section{Figure 4}

\section{Differences in Scores per Grade}

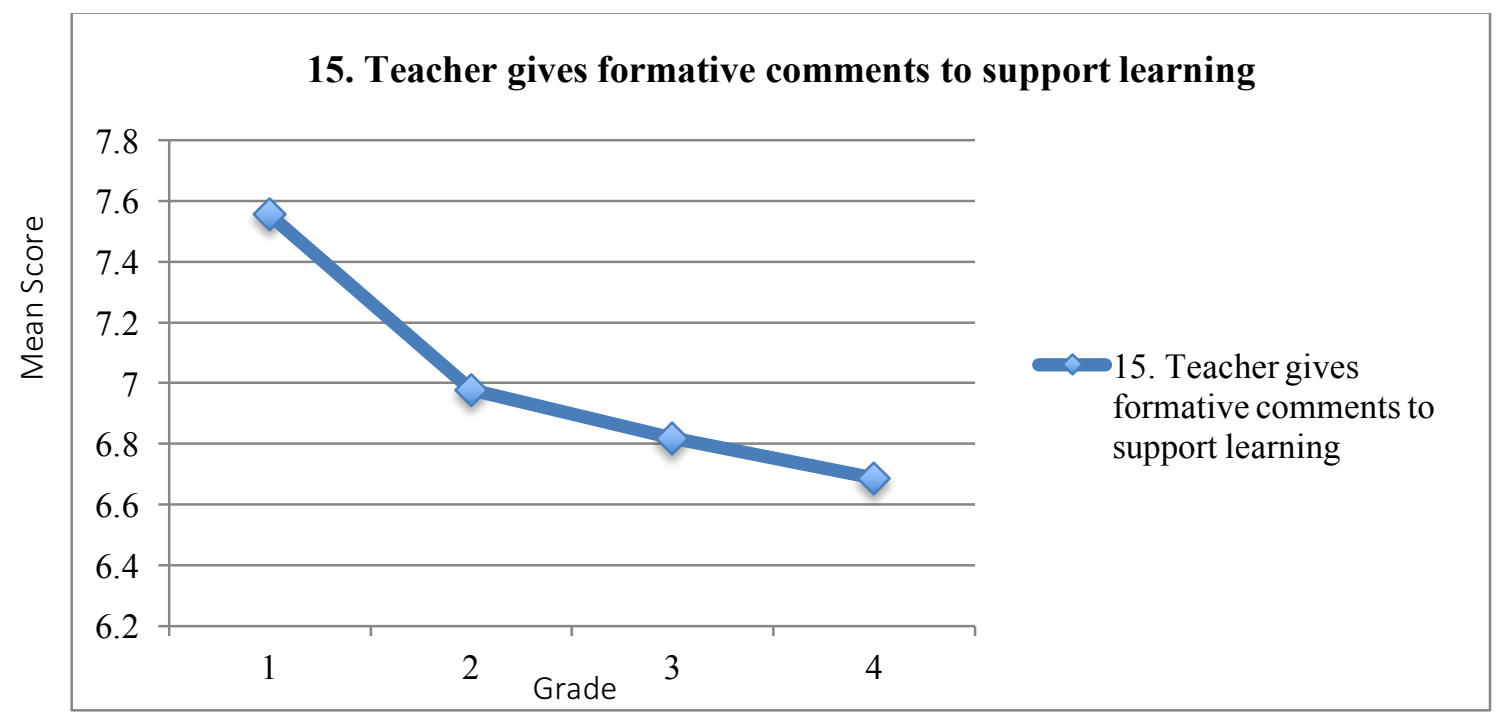

Here we observe how student perception regarding formative feedback decreases from the first to the fourth grade. The perception of formative feedback decreasing over the years follows a pattern supported by the theory of diminishing returns (Gupta et al., 2018). Similar observations can be made with other items. The results of all items identified per school and per grade, as well as comparing student and teacher populations, allowed for each school and group to be profiled, which guided the discussion about the application of KBIP in each case. These particularities contributed toward a meaningful assessment of implementing KBIP in each school. 


\section{The Evaluative Phase}

After studying the results, a reflective and evaluative process developed by the entire research team followed the DBR cycle, calling into question the profundity of the experience. This more dialogic processes needed to be complemented with more systemic research (Arnseth \& Ludvigsen, 2006). By evaluating perceptions about the 12 principles of learning via KB (Scardamalia, 2002), researchers structured the second survey (Appendix B) to elicit student and teacher responses.

\section{Figure 5}

\section{Higher Scores in Survey 2}

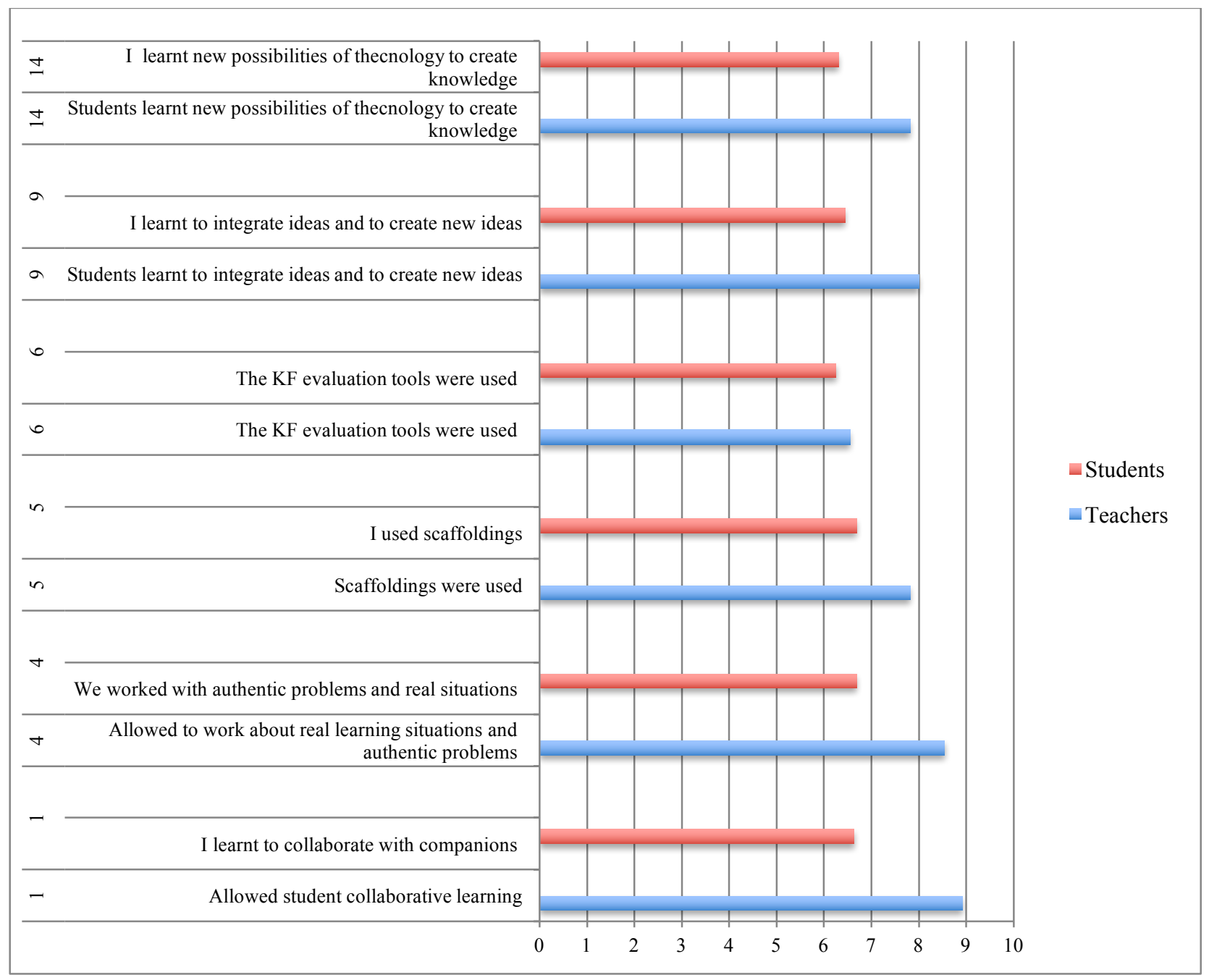




\section{Figure 6}

\section{Lower Scores in Survey 2}

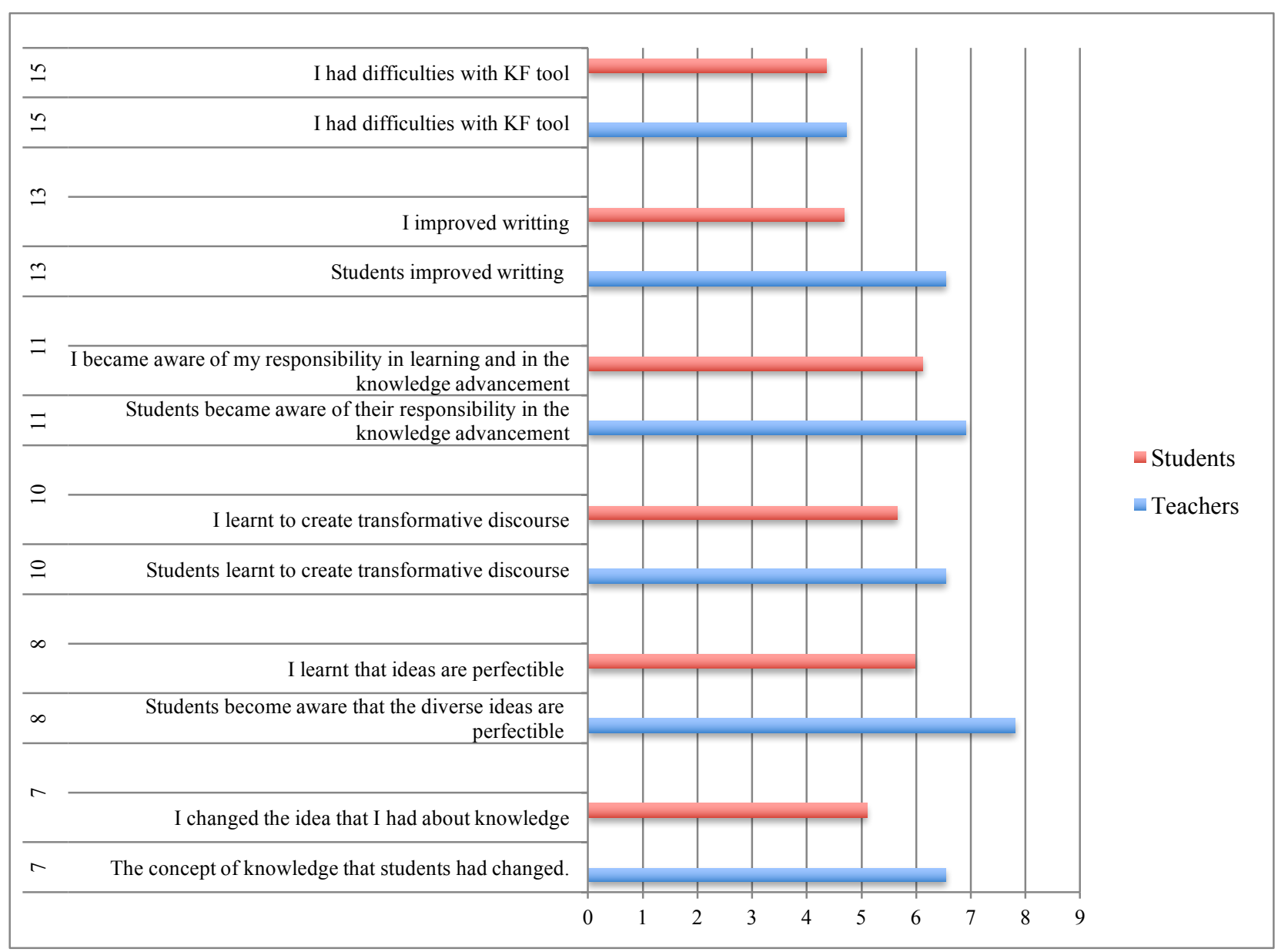

Student responses in general showed less involvement in items related to $\mathrm{KB}$ compared with the more technical and concrete items. This prompted the research team to consider the degree of awareness about the process of $\mathrm{KB}$ on the part of the students. For that reason, the research team decided to analyze the use of scaffoldings that can be obtained from the evaluation of the $\mathrm{KF}^{\mathrm{TM}}$ tools (Table 3).

\section{Table 3}

\section{Use of Scaffolding}

\begin{tabular}{lc}
\hline Scaffold & Percent \\
\hline New information & $24.77 \%$ \\
My theory & $46.07 \%$ \\
I need to understand & $14.11 \%$ \\
This theory cannot explain & $1.18 \%$ \\
A better theory & $6.68 \%$ \\
Putting knowledge together & $7.19 \%$ \\
Number of analyzed scaffoldings & $>500 \backslash 0$ \\
\hline
\end{tabular}


A single analysis of the scaffolds used regarding knowledge construction, represented by the last three items listed in Table 3, show only a 15\% use whereas those less involved with KB were much higher. The ratio of KB was 1/5.66 (one KB-oriented contribution for each 5.66 of the more general contributions).

Combining these scaffolding results with the overall evaluation supported an assessment of the KB process regarding profundity, producing recommendations for more involvement in the process of knowledge creation through KB. This would help students become more aware of the cognitive aspects of learning, taking into account both dialogical and systemic aspects of the research results (Arnseth \& Ludvigsen, 2006). The results also highlighted a need to make the metacognitive processes involved more explicit. Increasing the use of scaffolding oriented to knowledge construction will cause students to be more conscious about the KB process. Teachers regularly use the $\mathrm{KF}^{\mathrm{TM}}$ evaluation tools; more frequent use by students will help achieve this goal. While teachers reported that rich oral discussions and debates were produced during classroom interventions, this richness was not reflected in the $\mathrm{KF}^{\mathrm{TM}}$ evaluation. Therefore, maximizing the use of $\mathrm{KF}^{\mathrm{TM}}$ was recommended.

The method also allowed studying data about KB per school and per grade.

\section{Figure 7}

School Profile: "My previous idea about knowledge changed"

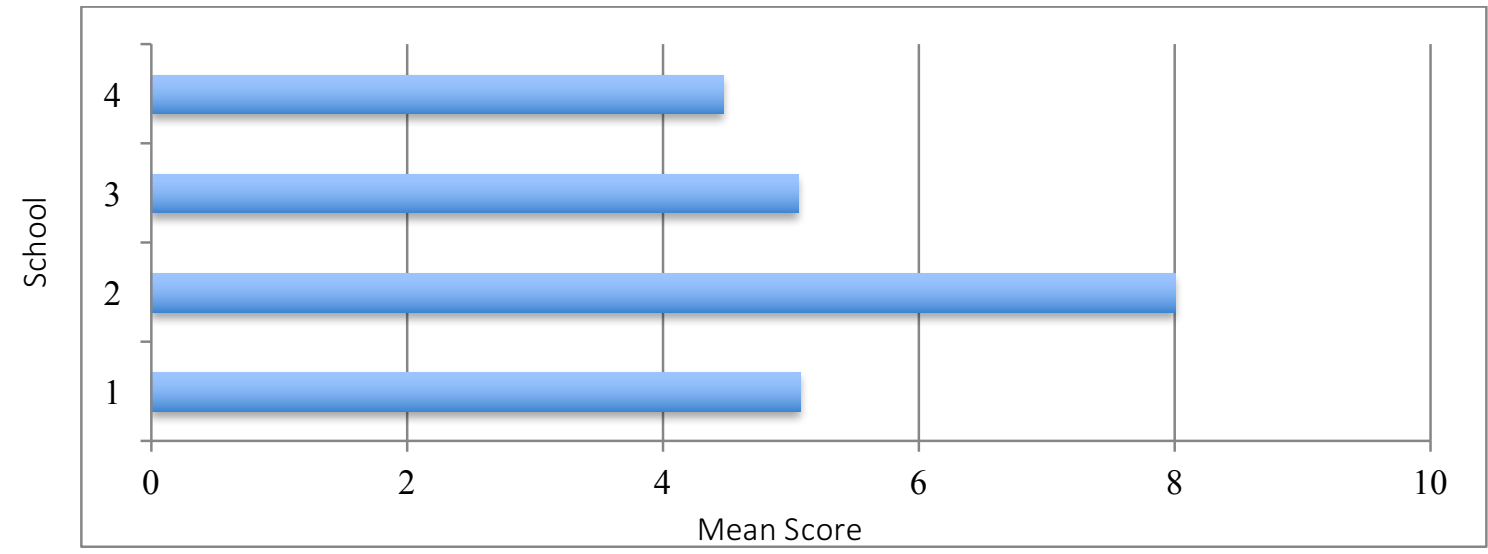

\section{Figure 8}

Year Profile: "My previous idea about knowledge changed"

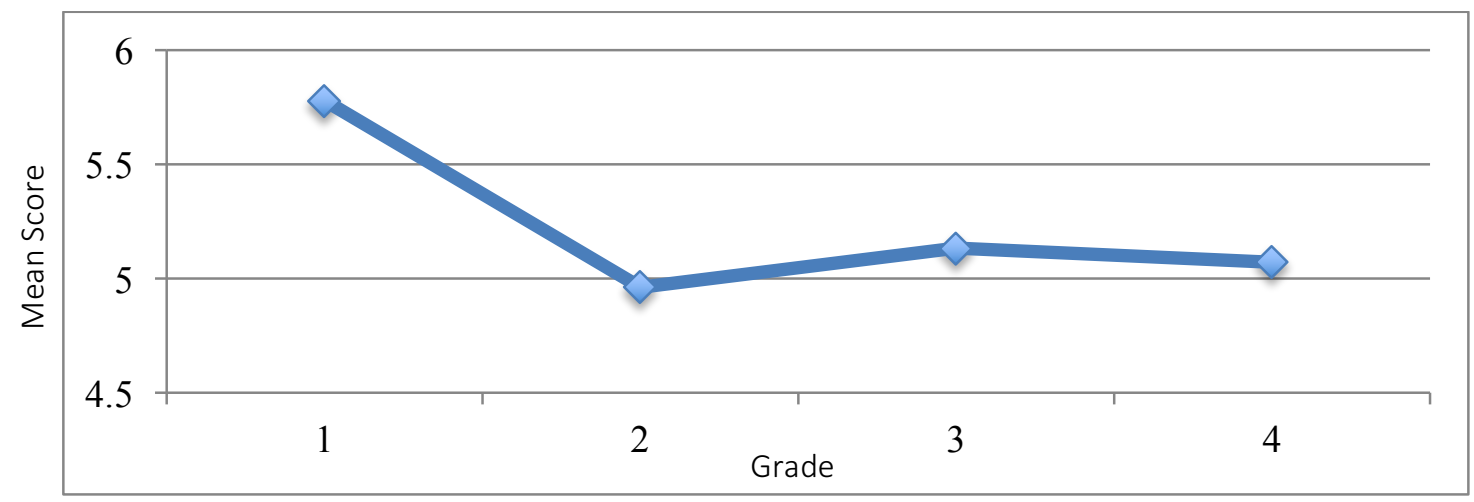


A qualitative analysis highlighted an unevenness in the participants' international relationship experience. Some experiences had positive outcomes, for example with Canada, Mexico, and Colombia, whereas others were not so positive due to a lack of engagement. Other results detected a feeling of isolation by teachers at their schools. While they did have the support of their principals, there was almost no involvement with other colleagues. Although KB can be understood as being a school within a school, that doesn't mean teachers need to feel alone. This situation may be improved by bringing more visibility to the experience.

Figures 9 and 10 represent the general evaluation of the experience in each school and in general.

\section{Figure 9}

\section{General Satisfaction with the KBIP Experience}

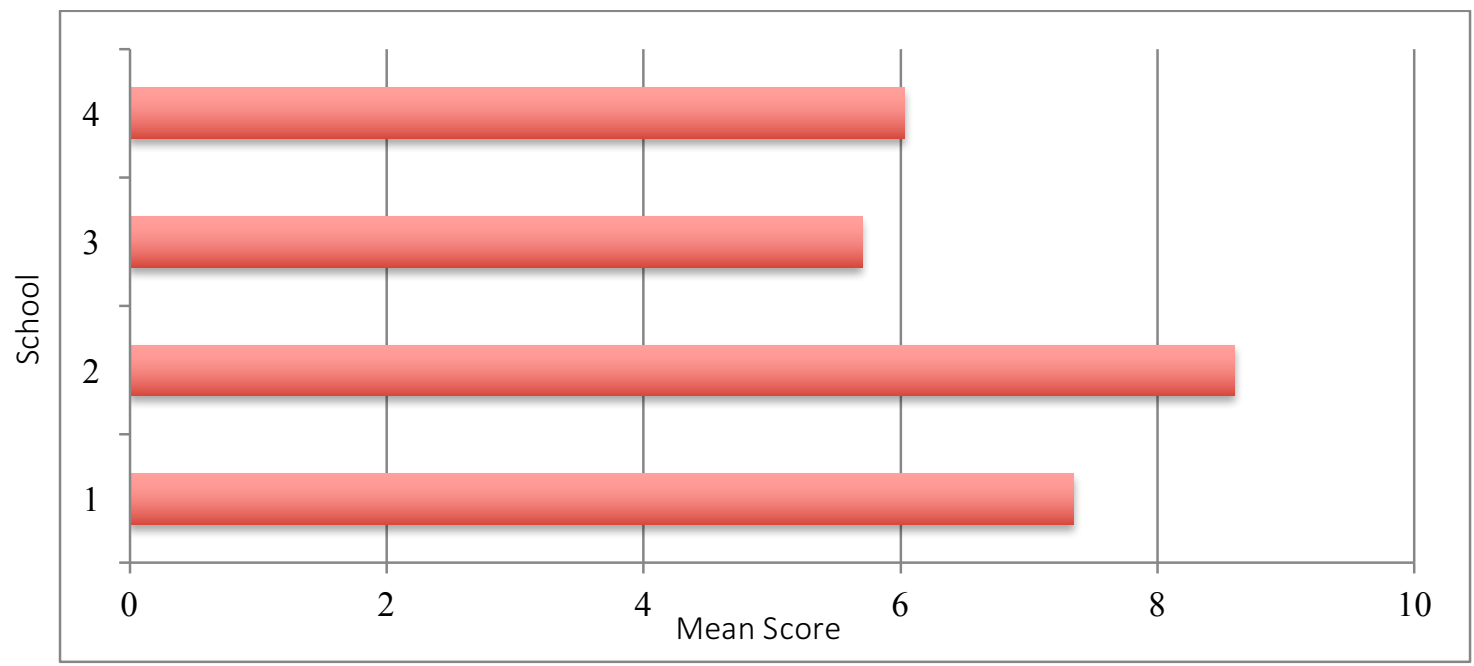

\section{Figure 10}

General Satisfaction with the KBIP Experience

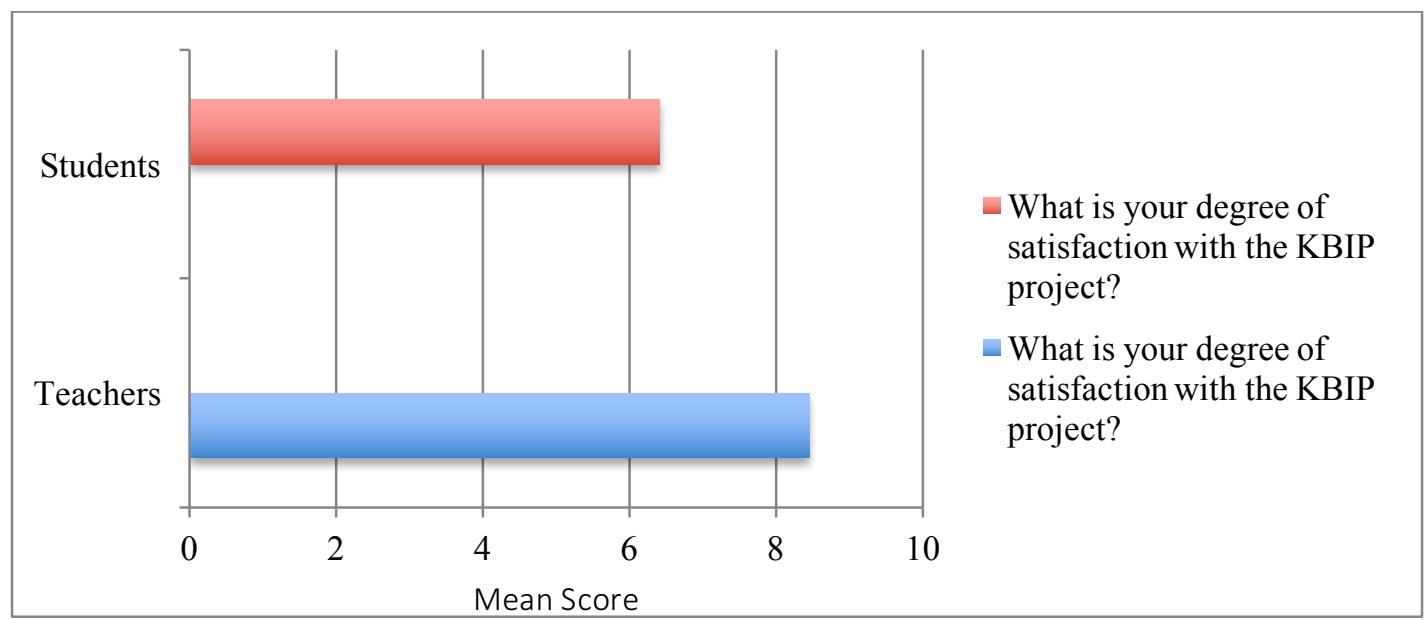

\section{Proposals for the Next Phase in the DBR Process}

Two recommendations came forth upon completion of the reflective process. First, the need to optimize the use of evaluation tools was a conclusion of the actual process, thus supporting the suggestion that a more precise evaluation be implemented in one of the schools. An expert in 
evaluation procedures would lead the process. This will allow teachers to discern evidence for improvement from the KF tools and make it available to students. After this improvement is implemented, the results will be generalized to the eight schools of the network.

Second, design and offer a master's degree program with the cooperation of other European universities for teacher training in KB and ILE. Part of this training will be based on the knowledge learned from the DBR process described herein. The DBR team will be implicated as instructors and faculty in this degree.

These points will start a new phase in the continuing process of DBR.

\section{Conclusion}

The KBIP implemented in Catalonia since 2004 incorporates the traits of an ILE as defined by the OECD. An analysis of the 2018-2019 study demonstrates KBIP as being perceived as more innovative than other ILEs in the context of innovative schools. The present work contributes to continuing the in-progress research of KBIP as ILE (Bereiter et al., 2016). A process of DBR was implemented and a method for the evaluation of KBIP as an ILE was created.

The method is useful to evaluate educational innovations in general, and, in particular, to evaluate innovation in the field of CSCL. Although DBR is less sophisticated than other research designs, it aligns better with the collaborative learning principles and the corresponding style of the research employed in this study. DBR research is more idiographic and serves to advance in a design process knowledge, using the design mode of thinking (Scardamalia \& Bereiter, 2017).

The results of this ongoing research demonstrate how KBIP contributes to a better conceptualization of an ILE (OECD, 2017) from the perspective of involved participants. In-depth learning about the KBIP experience can also help to better understand the ILE as defined by the OECD.

\section{Acknowledgements}

We want to thank the teachers involved in the DBR process: Pere Boluda, M. Carme Serrano, Teresa Morales, M. Carme Aragonès, Daniel Selva, Vicens Pedrón, Marta Rebollar, Elisabet Vicente, M. Montserrat Oliveras \& Jaume Bassedas. 


\section{References}

Akker, J. V. D., Gravemeijer, K., McKenney, S., \& Nieveen, N. (Eds.) (2006). Educational design research (11 Ed.). Routledge. https://doi.org/10.4324/9780203088364

Alegre, M. A., \& Ferrer, G. (2010). School regimes and education equity: some insights based on PISA 2006. British Educational Research Journal, 36(3), 433-461. https://doi.org/10.1080/01411920902989193

Arnseth, H. C., \& Ludvigsen, S. (2006). Approaching institutional contexts: Systemic versus dialogic research in CSCL. International Journal of Computer-Supported Collaborative Learning, 1(2), 167-185. https://doi.org/10.1007/s11412-006-8874-3

Bereiter, C. (2002). Design research for sustained innovation. Cognitive Studies, 9(3), 321-327. https://doi.org/10.11225/jcss.9.321

Bereiter, C., \& Scardamalia, M. (2010). Can children really create knowledge? Canadian Journal of Learning and Technology / La revue canadienne de l'apprentissage et de la technologie, 36(1), 1-15. https://doi.org/10.21432/T2ZP43

Bereiter, C., Scardamalia, M., Laferrière, T., Massey, L., Shaw, B. W., Chee, S., \& Istance, D. (2016). Beyond tried and true: The challenge of education for innovation. In C. K. Looi, J. Polman, U. Cress \& P. Reimann (Eds.), Transforming learning, empowering learners: The International Conference of the Learning Sciences (ICLS) 2016, Volume 1 (pp. 9-15). Singapore: International Society of the Learning Sciences. https://repository.nie.edu.sg/bitstream/10497/18023/1/ICLS-2016-9_a.pdf

Blackmore, C. (2010). Managing systemic change: Future roles for social learning systems and communities of practice? In C. Blackmore. Social learning systems and communities of practice (pp. 201-219). Springer. https://doi.org/10.1007/978-1-84996-133-2_12

Blackmore, J., Bateman, D., Cloonan, A., Dixon, M., Loughlin, J., O’Mara, J., \& Senior, K. (2011). Innovative learning environments research study. Department of Education and Early Childhood Development. Deakin University.

$\mathrm{http} / / / \mathrm{www}$. learningspaces.edu.au/docs/learningspaces-final-report.pdf

Brand, S., Felner, R., Shim, M., Seitsinger, A., \& Dumas, T. (2003). Middle school improvement and reform: Development and validation of a school-level assessment of climate, cultural pluralism, and school safety. Journal of Educational Psychology, 95(3), 570-588. https://doi.org/10.1037/0022-0663.95.3.570

Collins, A. (1992). Toward a design science of education. In E. Scanlon \& T. O’Shea (Eds.) New directions in educational technology. NATO ASI series (Series F: Computer and systems sciences), vol 96 (pp. 15-22). Springer. https://doi.org/10.1007/978-3-642-77750-9_2

Consell Superior d'Avaluació del Sistema Educatiu de Catalunya. (2006). Avaluació del projecte COMconèixer. L'aprenentatge a través de comunitats virtuals. Documents. N. 8. Barcelona: Consell Superior d'Avaluació, Generalitat de Catalunya. 
Consell Superior d'Avaluació del Sistema Educatiu de Catalunya. (2015). Avaluació del projecte COMconèixer 2014. Documents. N. 32. Barcelona: Consell Superior d'Avaluació, Generalitat de Catalunya.

Dexter, S., \& Richardson, J. W. (2019). What does technology integration research tell us about the leadership of technology? Journal of Research on Technology in Education, 59(3), 1-20. https://doi.org/10.1080/15391523.2019.1668316

Fullan, M. (2005). Leadership \& sustainability: System thinkers in action. Corwin Press.

Gallifa, J. (2009a). An approach to find out students' motives and influences in the selection of studies and University. Results from six years of continuing institutional research in a multicampus system in Spain. Tertiary Education and Management, 15(2), 173-191. https://doi.org/10.1080/13583880902869539

Gallifa, J. (2009b). Professional integration in higher education: A methodological approach applied to a multi-campus system in Spain. Journal of Higher Education Policy and Management, 31(3), 229-237. https://doi.org/10.1080/13600800902974302

Gallifa, J. (2018a). Paradigms and methodologies for Knowledge Building. Review of Educational Theory, 1(3), 70-81. https://ojs.bilpublishing.com/index.php/ret/article/view/70

Gallifa, J. (2018b). Research traditions in social sciences and their methodological rationales. Aloma, Revista de Psicologia, Ciències de l'Eduació i de l'Esport, 36(2), 9-20. https://doi.org/10.51698/aloma.2018.36.2.9-20

Gallifa, J., \& Batallé, P. (2010). Student perceptions of service quality in a multi-campus higher education system in Spain. Quality Assurance in Education, 18(2), 156-170. https://doi.org/10.1108/09684881011035367

Gray, K. C. (2001). Teachers' perceptions of innovation adoption. Action in Teacher Education, 23(2), 30-35. https://doi.org/10.1080/01626620.2001.10463061

Greenberg, S., \& Buxton, B. (2008). Usability evaluation considered harmful (some of the time). Proceedings of the twenty-sixth annual CHI conference on human factors in computing systems (pp. 111-120). CHI. https://doi.org/10.1145/1357054.1357074

Gupta, M. R., Bahri, D., Cotter, A., \& Canini, K. (2018). Diminishing returns shape constraints for interpretability and regularization. In Proceedings of the 32nd International Conference on Neural Information Processing Systems (pp. 6835-6845).

https://proceedings.neurips.cc/paper/2018/file/caa202034f268232c26fac9435f54e15Paper.pdf

Harris, J., Mishra, P., \& Koehler, M. (2009). Teachers' technological pedagogical content knowledge and learning activity types. Journal of Research on Technology in Education, 41(4), 393-416. https://doi.org/10.1080/15391523.2009.10782536

Istance, D., \& Dumont, H. (2010). Future directions for learning environments in the $21^{\text {st }}$ century. In Benavides, F., Dumont, H., \& Istance, D. (Eds.). The nature of learning: Using research to inspire practice (pp. 317-338). Educational Research and Innovation, OECD Publishing. https://doi.org/10.1787/9789264086487-15-en 
Järvelä, S., Hakkarainen, K., Lehtinen, E., \& Lipponen, L. (2001). Creating computer supported collaborative learning in Finnish schools: Research perspectives on sociocognitive effects. International Journal of Continuing Engineering Education and Life-Long Learning, 11(4/5/6), 365. https://doi.org/10.1504/ijceell.2001.000406

Law, N. (2005). Assessing learning outcomes in CSCL settings. In Proceedings of the 2005 conference on computer support for collaborative learning: Learning 2005: The next 10 years! (pp. 373-377). International Society of the Learning Sciences. https://dl.acm.org/doi/10.5555/1149293.1149342

Looney, J. (2009). Assessment and innovation in education. OECD Education Working Papers, No. 24. OECD Publishing. http://dx.doi.org/10.1787/222814543073

Mateo, J., Estruch, J., Ranchal, F., \& Amorós, C. (2016). A description and reflection on the different stages of the evaluative cycle of the educational innovation. Journal of the World Federation of Associations of Teacher Education, 1(3a), 132-144.

https://www.worldfate.org/docpdf/journal_01-03a.pdf

McKenney, S. (2001). Computer-based support for science education materials developers in Africa: Exploring potentials. (Publication No. 9036516420) [Doctoral dissertation, University of Twente]. University of Twente Research Information. https://ris.utwente.nl/ws/portalfiles/portal/6080267/thesis_S_McKenney.pdf

Nieveen, N. (1999). Prototyping to reach product quality. In Dalam J. Van Den Akker, et al. (Eds.). Design approaches and tools in education and training (pp. 125-135). Kluwer Academic Publishers. https://doi.org/10.1007/978-94-011-4255-7_10

OECD. (2013). Innovative learning environments. Educational research and innovation. OECD Publishing. https://doi.org/10.1787/20769679

OECD. (2017). The OECD handbook for innovative learning environments. OECD Publishing. https://doi.org/10.1787/9789264277274-en

Plomp, T., \& Nieveen, N. (Eds.). (2010). An introduction to educational design research:

Proceedings of the seminar conducted at the East China Normal University, Shanghai. SLO Netherlands Institute for Curriculum Institute.

https://ris.utwente.nl/ws/portalfiles/portal/14472302/Introduction_20to_20education_20desig n_20research.pdf

Reeves, T. C., Herrington, J., \& Oliver, R. (2002). Authentic activities and online learning. In HERDSA 2002 quality conversations (pp. 562-567). Edith Crown University. https://ro.ecu.edu.au/cgi/viewcontent.cgi?article=4899\&context=ecuworks

Scardamalia, M. (2002). Collective cognitive responsibility for the advancement of knowledge. Liberal Education in a Knowledge Society, 97, 67-98. https://www.ikit.org/fulltext/inpressCollectiveCog.pdf

Scardamalia, M., \& Bereiter, C. (2006). Knowledge building. In K. Sawyer (Ed.), Cambridge handbook of the learning sciences (pp. 97-116). Cambridge University Press. https://doi.org/10.1017/cbo9780511816833.008 
Scardamalia, M., \& Bereiter, C. (2010). A brief history of knowledge building. Canadian Journal of Learning and Technology/La revue canadienne de l'apprentissage et de la technologie, 36(1), 1-16. https://doi.org/10.21432/T2859M

Scardamalia, M., \& Bereiter, C. (2014). Knowledge building and knowledge creation: Theory, pedagogy and technology. In R. K. Sawyer (Ed.), The Cambridge handbook of the learning sciences $\left(2^{\text {nd }}\right.$ ed.) (pp. 397-417). Cambridge University Press.

https://doi.org/10.1017/CBO9781139519526.025

Scardamalia, M., \& Bereiter, C. (2017). Two modes of thinking in knowledge building. Revista Catalana de Pedagogia, 11, 61-83.

https://raco.cat/index.php/RevistaPedagogia/article/view/97331 


\section{Appendix A: Knowledge Building International Project}

The survey addressed to teachers and external connoisseurs (items 1-27 only). Data will be used only for research purposes. * Mandatory

1. Relationship with KBIP*:
A- Teacher
B- Director
C- Coordinator
D- Student's family
D- Other external connoisseurs of KBIP

2. School Name*:

3. School year*:

4. Class*:

5. Area/curricular areas where KBIP is applied:

Please respond to each of the following statements showing the degree of agreement with each one of them:

\begin{tabular}{|l|l|l|}
\hline & $\begin{array}{l}\text { A-More (in) } \\
\text { KBIP } \\
\text { B- More (in) } \\
\text { other active } \\
\text { learning } \\
\text { environments }\end{array}$ & $\begin{array}{l}\text { Thinking in KBIP, } \\
\text { what is your degree of } \\
\text { agreement? } \\
\text { 0- Strongly Disagree; } \\
\text { 1- Disagree; } \\
\text { 2- Slightly Disagree; } \\
\text { 3- Slightly Agree; } \\
\text { 4- Agree; } \\
\text { 5- Strongly Agree }\end{array}$ \\
\hline $\begin{array}{l}\text { 1.The students are the core participants } \\
\text { 2. Encourages the active engagement of the students } \\
\text { 3. Develops in the students an understanding of their } \\
\text { activity as learners }\end{array}$ & & \\
\hline 4. Is founded in the social nature of learning & & \\
\hline $\begin{array}{l}\text { 5. Actively encourages well-organized cooperative } \\
\text { learning }\end{array}$ & & \\
\hline $\begin{array}{l}\text { 6. Teachers are highly attuned to the learners' } \\
\text { motivations }\end{array}$ & & \\
\hline $\begin{array}{l}\text { 7. Teachers are highly attuned to the key role of } \\
\text { emotions in achievement }\end{array}$ & & \\
\hline $\begin{array}{l}\text { 8. It's very sensitive to the individual differences } \\
\text { among learners }\end{array}$ & & \\
\hline 9. It includes prior knowledge of students & & \\
\hline 10. It demands hard work of students & & \\
\hline
\end{tabular}




\begin{tabular}{|c|c|c|}
\hline 11. It's a challenge from all & & \\
\hline 12. Requires excessive overload for students (Op) & & \\
\hline 13. It operates with clarity of expectations & & \\
\hline $\begin{array}{l}\text { 14. It deploys assessment strategies consistent with } \\
\text { expectations }\end{array}$ & & \\
\hline $\begin{array}{l}\text { 15. There is a strong emphasis on "formative } \\
\text { feedback" to support learning }\end{array}$ & & \\
\hline $\begin{array}{l}\text { 16. It strongly promotes "horizontal connectedness" } \\
\text { across areas of knowledge }\end{array}$ & & \\
\hline $\begin{array}{l}\text { 17. It strongly promotes "horizontal connectedness" } \\
\text { across subjects }\end{array}$ & & \\
\hline $\begin{array}{l}\text { 18. It strongly promotes "horizontal connectedness" to } \\
\text { the community and the wider world }\end{array}$ & & \\
\hline $\begin{array}{l}\text { 19. It is innovative in the basic elements (learners, } \\
\text { educators, content, resources for learning) }\end{array}$ & & \\
\hline $\begin{array}{l}\text { 20. It is innovative in pedagogy, use of time, } \\
\text { organization of educators and learners }\end{array}$ & & \\
\hline 21. It is innovative in formative evaluation & & \\
\hline $\begin{array}{l}\text { 22. It allows turning the class into a "formative } \\
\text { organization" }\end{array}$ & & \\
\hline 23. There are strong learning leaderships & & \\
\hline $\begin{array}{l}\text { 24. The achievements are constantly informed by the } \\
\text { evidence about the learning }\end{array}$ & & \\
\hline $\begin{array}{l}\text { 25. Different strategies and innovations are applied to } \\
\text { obtain pieces of evidence }\end{array}$ & & \\
\hline $\begin{array}{l}\text { 26. It allows to open up to partnerships by working } \\
\text { with families and communities, higher education, } \\
\text { cultural institutions, media, business, and especially } \\
\text { other schools }\end{array}$ & & \\
\hline $\begin{array}{l}\text { 27. Open up to partnerships by working with learning } \\
\text { environments in ways that directly shape the } \\
\text { pedagogical core and the learning leadership. }\end{array}$ & & \\
\hline
\end{tabular}

Please respond to these items having in mind the KBIP application in the actual year:

\begin{tabular}{|l|l|}
\hline & $\begin{array}{l}\text { 0- Strongly Disagree; 1- } \\
\text { Disagree; 2- Slightly } \\
\text { Disagree; 3- Slightly Agree; } \\
\text { 4- Agree; 5- Strongly Agree }\end{array}$ \\
\hline 28. Has allowed the cooperative learning of the students & \\
\hline 29. Has allowed the cooperative learning of the teaching team & \\
\hline 30. The topics chosen to work with have been adequate & \\
\hline $\begin{array}{l}\text { 31. Has allowed working in real situations of learning and } \\
\text { authentic problems }\end{array}$ & \\
\hline
\end{tabular}




\begin{tabular}{|c|c|}
\hline 32. All the scaffoldings have been used & \\
\hline 33. The KF evaluation tools have been used & \\
\hline $\begin{array}{l}\text { 34. The concept that the students had about knowledge has } \\
\text { changed }\end{array}$ & \\
\hline $\begin{array}{l}\text { 35. The students took consciousness that the diverse ideas are } \\
\text { perfectible }\end{array}$ & \\
\hline $\begin{array}{l}\text { 36. Students have learned to integrate ideas and make new ideas } \\
\text { emerge }\end{array}$ & \\
\hline 37. The students have learned to create transformative discourse & \\
\hline $\begin{array}{l}\text { 38. The students have become aware of their responsibility in the } \\
\text { advancement of knowledge }\end{array}$ & \\
\hline $\begin{array}{l}\text { 39. Collaboration with educational centers in other countries has } \\
\text { been successful }\end{array}$ & \\
\hline 40. The students have improved writing & \\
\hline $\begin{array}{l}\text { 41. The students have learned new possibilities of the technology } \\
\text { to create knowledge }\end{array}$ & \\
\hline 42. The KBIP has favored equity & \\
\hline 43. The KBIP has favored the learning of languages & \\
\hline $\begin{array}{l}\text { 44. The KBIP has encouraged learning about the use of digital } \\
\text { technologies }\end{array}$ & \\
\hline 45. Teachers have received adequate training & \\
\hline 46. I have had difficulties with the KF tool (Op) & \\
\hline $\begin{array}{l}\text { 47. The relationship with the faculties of Education has been } \\
\text { useful }\end{array}$ & \\
\hline 48. The work with the coordinating team has been satisfactory & \\
\hline $\begin{array}{l}\text { 49. At your school, you have detected the interest of other } \\
\text { teachers in the project }\end{array}$ & \\
\hline $\begin{array}{l}\text { 50. At your school, you have received the support of the } \\
\text { principal }\end{array}$ & \\
\hline
\end{tabular}

General evaluations

0-Completely unsatisfied - 1- 2-3-4-5-6-7-8-9-10-Completely satisfied

What is your general level of satisfaction about the KBIP project?

Suggestions for improvement:

Other suggestions: 


\section{Appendix B: Survey for Students that Participated in the Knowledge Based International Project}

The data will be used only for research purposes. * Mandatory

1. School Name*:

2. School year*:

3. Class*:

Please respond to the statements that follow below, expressing the degree of agreement with each one of them

\begin{tabular}{|c|c|c|}
\hline & $\begin{array}{l}\text { A- More (in) } \\
\text { KBIP } \\
\text { B- More (in) } \\
\text { other active } \\
\text { learning } \\
\text { environments }\end{array}$ & $\begin{array}{l}\text { Thinking in KBIP, what is } \\
\text { your degree of agreement? } \\
\text { 0- Strongly Disagree; } \\
\text { 1-Disagree; } \\
\text { 2-Slightly Disagree; } \\
\text { 3-Slightly Agree; } \\
\text { 4-Agree; } \\
\text { 5-Strongly Agree }\end{array}$ \\
\hline $\begin{array}{l}\text { 1. We, the students, are the central } \\
\text { protagonists of learning }\end{array}$ & & \\
\hline 2. We are engaged in the activity & & \\
\hline 3. I understand what does it means to learn & & \\
\hline 4. I build knowledge with others & & \\
\hline 5. I learn cooperatively in an organized way & & \\
\hline 6. Teachers are attentive to our motivations & & \\
\hline $\begin{array}{l}\text { 7. Teachers are attentive to our emotions while } \\
\text { we are learning }\end{array}$ & & \\
\hline $\begin{array}{l}\text { 8. I understand the differences in how my } \\
\text { classmates learn }\end{array}$ & & \\
\hline 9. Our prior knowledge is taken into account & & \\
\hline 10. The activities need hard work & & \\
\hline 11. Learning is a challenge & & \\
\hline $\begin{array}{l}\text { 12. There are overloads with difficult tasks } \\
\text { and/or exercises }\end{array}$ & & \\
\hline $\begin{array}{l}\text { 13. Always know what to do and what is } \\
\text { expected }\end{array}$ & & \\
\hline 14. There is a consistent assessment & & \\
\hline $\begin{array}{l}15 . \text { The teacher makes formative comments to } \\
\text { support learning }\end{array}$ & & \\
\hline $\begin{array}{l}\text { 16. I work at the same time on different } \\
\text { subjects }\end{array}$ & & \\
\hline 17. We work on a variety of topics & & \\
\hline
\end{tabular}




\begin{tabular}{|l|l|l|}
\hline $\begin{array}{l}\text { 18. We connect with the outside world of the } \\
\text { school }\end{array}$ & & \\
\hline $\begin{array}{l}\text { 19. We work innovatively } \\
\text { 20. I feel part of a formative group }\end{array}$ & & \\
\hline 21. There are learning leaderships & & \\
\hline $\begin{array}{l}\text { 22. I am constantly informed about the } \\
\text { learning I was achieving }\end{array}$ & & \\
\hline $\begin{array}{l}\text { 23. It allows us to open and collaborate with } \\
\text { other external associations (families, cultural } \\
\text { institutions, the media, companies, etc.) }\end{array}$ & & \\
\hline $\begin{array}{l}\text { 24. It allows us to collaborate with other } \\
\text { schools }\end{array}$ & & \\
\hline
\end{tabular}

Please respond sincerely to these items having in mind the KBIP application in the actual year:

(0-Strongly Disagree; 1-Disagree; 2-Slightly Disagree; 3-Slightly Agree; 4-Agree; 5-Strongly Agree)

\begin{tabular}{|l|l|}
\hline 25. I learned to collaborate with my classmates & \\
\hline 26. I have learned new contents with the topics worked & \\
\hline 27. I have worked on real problems and real situations & \\
\hline 28. I used the diverse scaffoldings & \\
\hline 29. The KBIP evaluation tools have been used & \\
\hline 30. I changed the idea I had about knowledge & \\
\hline 31. I learned that ideas are perfectible & \\
\hline 32. I learned to integrate ideas and make emerge new ones & \\
\hline 33. I learned to create transformative discourse & \\
\hline $\begin{array}{l}\text { 34. I have become aware of my responsibility as a learner for the } \\
\text { advancement of knowledge }\end{array}$ & \\
\hline 35. Collaboration with centers from other countries has been great & \\
\hline 36. I have improved the writing & \\
\hline 37. I learned new possibilities of technology to create knowledge & \\
\hline 38. I have had difficulties with the KF tool & \\
\hline
\end{tabular}

0-Completely unsatisfied - 1- 2-3-4-5-6-7-8-9-10-Completely satisfied

What is your general degree of satisfaction with the KBIP project?

Suggestions for improvement: 


\section{Authors}

Josep Gallifa, $\mathrm{PhD}$, is a full professor of Psychology and Education and deparment head in the FPCEE Blanquerna, Ramon Llull University, Barcelona. He conducts research on Integral Education and Development and Higher Education. Email: josepgr@blanquerna.url.edu

Mireia Montané, PhD, is the Past President of the ATEE and WFATE. She directs the KBIP project in Catalonia and works in the Col.legi de Doctors i Llicenciats en Filosofia i Lletres i en Ciències de Catalunya, Barcelona. Email: mireiamontane@me.com

Sandra Lund, is involved in different research projects on International Education and Enterpreneurship Education in Global Skills Network S.L., Barcelona. Email: info@globalskillsnetwork.com

Carme Amorós, works as a coordinator of the KBIP project in Catalonia and is member of the Societat Catalana de Pedagogia, Institut d'Estudis Catalans. Email: carme.amoros@gmail.com

Mercè Bernaus, $\mathrm{PhD}$, is a retired professor specilizing in Plurilingualism and Pluriculturalism and Language Didaktics in the Universitat Autònoma de Barcelona. Facultat de Ciències de l'Educació. Email:merce.bernaus@uab.cat

Mercè Gisbert, $\mathrm{PhD}$, is a full professor and works in Education and Technology in the Universitat Rovira i Virgili. Facultat d'Educació i Psicologia. Email: merce.gisbert@urv.cat

Francesc Martínez-Olmo, $\mathrm{PhD}$, works in Evaluation and Measurement in Education in the Facultat d'Educació, Universitat de Barcelona, Barcelona. Email: fmartinezo@ub.edu

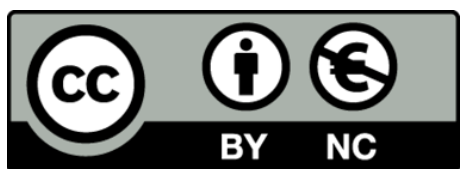

